\title{
Spatiotemporal distribution and microbial assimilation of polyamines in a mesotrophic lake
}

Krempaska, Natalia ; Horňák, Karel ; Pernthaler, Jakob

\begin{abstract}
We examined seasonal and spatial variations of dissolved free polyamines (DFPA) in the large mesotrophic prealpine Lake Zurich (Switzerland). An ion-pairing liquid chromatography method with mass spectrometric detection was optimized for the quantification of DFPA without prior concentration or derivatization. Total DFPA concentrations varied between $0.4 \mathrm{nM}$ and $11 \mathrm{nM}$ in winter and spring of 2015, respectively. Polyamine concentrations were highest in the epilimnion during the phytoplankton growth phase, and reflected occurrence patterns of diatoms. Putrescine consistently dominated the DFPA pool throughout the season whereas norspermidine was detected only once in spring. Incubations with 13C-labeled putrescine revealed concentrationdependent uptake rates $(3.2-5 \mathrm{nM} \mathrm{h-1)}$ and short turnover times (2.4-4.4 h). In contrast, incorporation rates into biomass measured with $14 \mathrm{C}$-labeled putrescine were substantially lower $(0.9 \mathrm{nM} \mathrm{h}-1)$, indicating that this compound was predominantly respired. Uptake kinetics moreover suggested that putrescine in situ uptake rates were limited by low ambient concentrations. Competition assays revealed that putrescine uptake could only be inhibited by excess concentrations of another polyamine (spermidine), but not by amino acids. Bacteria affiliated with Limnohabitans and the acI lineage of Actinobacteria were identified as the taxa with the highest fraction (25-32\%) of putrescine-incorporating cells. This compound was also utilized by Alphaproteobacteria, Cyclobacteriaceae, diatoms, and cyanobacteria. Overall, our data point to fast turnover of putrescine by different microorganisms, implying the importance of this substrate as an attractive energy source.
\end{abstract}

DOI: https://doi.org/10.1002/lno.10672

Posted at the Zurich Open Repository and Archive, University of Zurich

ZORA URL: https://doi.org/10.5167/uzh-145578

Journal Article

Accepted Version

Originally published at:

Krempaska, Natalia; Horňák, Karel; Pernthaler, Jakob (2018). Spatiotemporal distribution and microbial assimilation of polyamines in a mesotrophic lake. Limnology and Oceanography, 63(2):816-832.

DOI: https://doi.org/10.1002/lno.10672 
1 Spatiotemporal distribution and microbial assimilation of polyamines in a mesotrophic

2 lake

3

$4 \quad$ Natalia Krempaska, Karel Horňák*, Jakob Pernthaler

5

6 Limnological Station, Department of Plant and Microbial Biology, University of Zurich,

$7 \quad$ Kilchberg, Switzerland

8

9 Correspondence: khornak@limnol.uzh.ch

10 Phone: +41 (0)44 6349212

11 Fax: +41(0)446349225

12

13

14 Running head: Polyamine variability and bacterial assimilation

15

16 Key words: Polyamines, spatiotemporal variability, freshwater bacteria, HPLC-mass

17 spectrometry, uptake, turnover, transporter kinetics, bacterial assimilation, MAR-FISH,

18 Actinobacteria, Limnohabitans 
Polyamine variability and bacterial assimilation

19

20

21

22

\section{Abstract}

We examined seasonal and spatial variations of dissolved free polyamines (DFPA) in the large mesotrophic prealpine Lake Zurich (Switzerland). An ion-pairing liquid chromatography method with mass spectrometric detection was optimized for the quantification of DFPA without prior concentration or derivatization. Total DFPA concentrations varied between 0.4 and $11 \mathrm{nM}$ in winter and spring of 2015, respectively. Polyamine concentrations were highest in the epilimnion during the phytoplankton growth phase, and reflected occurrence patterns of diatoms. Putrescine consistently dominated the DFPA pool throughout the season whereas norspermidine was detected only once in spring. Incubations with ${ }^{13} \mathrm{C}$-labeled putrescine revealed concentration-dependent uptake rates $(3.2-$ $\left.5 \mathrm{nM} \mathrm{h}^{-1}\right)$ and short turnover times $(2.4-4.4 \mathrm{~h})$. In contrast, incorporation rates into biomass measured with ${ }^{14} \mathrm{C}$-labeled putrescine were substantially lower $\left(0.9 \mathrm{nM} \mathrm{h}^{-1}\right)$, indicating that this compound was predominantly respired. Uptake kinetics moreover suggested that putrescine in situ uptake rates were limited by low ambient concentrations. Competition assays revealed that putrescine uptake could only be inhibited by excess concentrations of another polyamine (spermidine), but not by amino acids. Bacteria affiliated with Limnohabitans and the acI lineage of Actinobacteria were identified as the taxa with the highest fraction $(25-32 \%)$ of putrescine-incorporating cells. This compound was also utilized by Alphaproteobacteria, Cyclobacteriaceae, diatoms and cyanobacteria. Overall, our data point to fast turnover of putrescine by different microorganisms, implying the importance of this substrate as an attractive energy source. 
Polyamine variability and bacterial assimilation

\section{Introduction}

Polyamines occur in every living cell and play an important role in various cellular processes, such as the stabilization of nucleic acids, transcription, translation, cell growth and proliferation, or the functioning of ion channels (Kusano et al. 2008). They also contribute to membrane stability and are involved in cellular stress responses (Tabor and Tabor 1985; Igarashi and Kashiwagi 2000; Jantaro et al. 2003). In aquatic systems polyamines are found in both, algae and bacteria (Hamana and Matsuzaki 1982, 1992). Phytoplankton exudation, viral lysis or grazing are among the key processes responsible for the release of dissolved free polyamines (DFPA) into the free water zone. Another important source of DFPA is the degradation of proteins and amino acids (Höfle 1984; Lu et al. 2014).

Current knowledge about the distribution, uptake, and fate of polyamines in aquatic systems is scarce, because most analyses of labile nitrogen-bearing organic compounds have been limited to amino acids. Only a few studies have examined DFPA concentrations in marine samples documenting that putrescine and spermidine typically dominate the DFPA pool (Lee and Jørgensen 1995; Nishibori 2001; Lu et al. 2014). However, DFPA concentrations and composition may temporarily change during phytoplankton blooms of diverse taxa (e.g. Chatonella spp., Gymnodinium spp.), when also unusual polyamines like norspermidine or caldopentamine could be present. These polyamines are mainly involved in growth regulation which is a function common to all polyamines (Nishibori and Nishijima 2004; Nishibori et al. 2009). The intracellular polyamine concentrations are usually at $\mu \mathrm{M}$ levels (Hamana and Matsuzaki 1982; Tabor and Tabor 1985) which contrasts their low sub$\mathrm{nM}$ to $\mathrm{nM}$ amounts in ambient waters, with marked temporal and depth variations (Lee and Jørgensen 1995; Nishibori et al. 2003; Lu et al. 2014). The low DFPA concentrations could be explained by their efficient uptake via specific transport systems (Tabor and Tabor 1966; 
Polyamine variability and bacterial assimilation

64 Igarashi and Kashiwagi 1999). Polyamine uptake rates are similar to those of amino acids,

65 but the fraction of polyamine-derived $\mathrm{C}$ assimilated by bacteria and the contribution of

66 polyamines to bacterial $\mathrm{C}$ and $\mathrm{N}$ demands is typically lower than for amino acids (Höfle

67 1984; Liu et al. 2015). Planktonic microorganisms capable of DFPA utilization are not well

68 characterized. Recent evidence from metagenomic data suggested that a substantial fraction

69 of marine bacterioplankton, including Roseobacter- and SAR11-affiliated bacteria, Alpha-,

70 Beta-, and Gammaproteobacteria, Actinobacteria and Flavobacteria, harbors genes for

71 transport and degradation of polyamines (Moran et al. 2007; Mou et al. 2011; Ghylin et al.

72 2014).

DFPA in seawater have been previously determined by liquid chromatography after a

74 one- or a two-step fluorometric derivatization (Nishibori 2001; Lu et al. 2014). Other methods based on liquid chromatography coupled to mass spectrometry (LC-MS) for the detection of underivatized polyamines have been applied in clinical (Häkkinen et al. 2013;

Gosetti et al. 2013) or in food quality control applications (Gosetti et al. 2007; Sirocchi et al. 2014). None of the previous detection methods has been applied to and validated for freshwater samples.

The goals of our study were to adapt a previously described technique employing ionpairing chromatography with mass spectrometric detection (Häkkinen et al. 2007) for the direct quantification of DFPA in lake water and to apply the optimized LC-MS method to examine the seasonal and spatial changes in DFPA concentrations in the large mesotrophic prealpine Lake Zurich (Switzerland). We also determined the uptake, incorporation and uptake kinetics of putrescine in short-term incubations with isotope-labeled tracers to assess its dynamics and importance to microbial consumers. Another objective was to investigate inhibition of putrescine uptake by a competition experiment with amino acids and another 
Polyamine variability and bacterial assimilation

88

polyamine to reveal uptake preferences of heterotrophic consumers for putrescine. Finally, we aimed to identify planktonic microbes involved in putrescine utilization by microautoradiography and fluorescence in situ hybridization (MAR-FISH). Based on previous studies (Moran et al. 2007; Mou et al. 2011; Ghylin et al. 2014), we hypothesized that putrescine will be assimilated by a broad range of planktonic bacteria.

\section{Materials and methods}

Reagents

Standard compounds 1,3-diaminopropane dihydrochloride (Dap, >98\%), 1,5-

diaminopentane dihydrochloride (Cad, >98\%), 1,7-diaminoheptane (Dah, internal standard, $>98 \%$ ) and Bis(3-aminopropyl) amine (Nsd, >98\%), N-(3-aminopropyl)-1,4-butanediamine trihydrochloride (Spd, $\geq 99.5 \%$ ) and $\mathrm{N}, \mathrm{N}^{\prime}$-Bis(3-aminopropyl)-1,4-butanediamine tetrahydrochloride (Spm, $\geq 99.5 \%$ ) were purchased from Sigma-Aldrich. 1,4-diaminobutane dihydrochloride (Put, $\geq 99.0 \%$ ) was obtained from Fluka. Structures of polyamines used in this study are shown in Suppl. Table $1.1,4-{ }^{13} \mathrm{C}$ butanediamine dihydrochloride $\left({ }^{13} \mathrm{C}\right.$-Put $)$ was from American Radiolabeled Chemicals, Inc. Heptafluorobutyric acid (HFBA, 99.5\%), propionic acid (PrA, 99.5\%) and formic acid (98\%) were from Sigma-Aldrich. LC-MS grade acetonitrile (ACN) was from J.T. Baker, Avantor. Water used for preparation of solvents and standard stock solutions was purified in a Milli-Q Direct 8 system (Millipore).

\section{Sampling}

Water samples were taken biweekly from 4 February to 21 October 2015 at the deepest point of Lake Zurich, a large mesotrophic prealpine lake (406 m above sea level, area $65.06 \mathrm{~km}^{2}$, max. depth $136 \mathrm{~m}$, mean depth $51.7 \mathrm{~m}$, residence time $440 \mathrm{~d}, 47^{\circ} 17^{\prime} \mathrm{N}, 8^{\circ} 36^{\prime} \mathrm{E}$, 
Polyamine variability and bacterial assimilation

112 Switzerland) (Bossard et al. 2001). The samples were collected with a Friedinger sampler at 113 depths of $0,5,10,20,30,40,60,80$ and $100 \mathrm{~m}$. Depths were selected according to an 114 ongoing long-term sampling campaign performed in Lake Zurich. Subsamples were filled in 115 sterile $50 \mathrm{~mL}$ plastic tubes and kept in a closed isolated box until further processing.

116 Sampling took place approximately at 10 a.m. and subsamples of $1 \mathrm{~mL}$ were filtered roughly $1171 \mathrm{~h}$ later employing syringe filters (IC Acrodisc filter, $0.2 \mu \mathrm{m}$ Supor membrane, PALL Life 118 Sciences) pre-washed with $1 \mathrm{~mL}$ of Milli-Q water. Samples were stored at $-24^{\circ} \mathrm{C}$ in $2 \mathrm{~mL}$ 119 glass vials (Glastechnik Gräfenroda) until analysis. In parallel, subsamples of $1 \mathrm{~mL}$ for 120 bacterial abundance were fixed with formalin (final concentration, 2\%), stained with 4',6121 diamidino-2-phenylindole (DAPI; final concentration, $1 \mu \mathrm{g} \mathrm{mL}^{-1}$ ) and quantified by flow 122 cytometry (inFlux V-GS, Becton Dickinson) as described previously (Salcher et al. 2011). 123 Vertical profiles of chlorophyll $a(\mathrm{Chl} a)$ concentrations were measured with a TS-16-12 124 fluoroprobe (bbe Moldaemke, Kronshagen, Germany). This multiple wavelength probe can 125 determine different phytoplankton groups such as diatoms, chlorophytes, cryptophytes and 126 the cyanobacterium Planktothrix rubescens based on different fluorescence excitation spectra 127 of the mentioned phototrophic organisms (Beutler et al. 2002). For incubations with stable 128 isotope and radiolabeled putrescine, samples from Lake Zurich were collected with a 129 Friedinger sampler at $5 \mathrm{~m}$ depth into $1 \mathrm{~L}$ glass bottles on 24 and 30 September 2015, 18 130 March 2016, 27 April 2016 and 6 July 2016 (incubations I - V). Additional samples from the 131 depth of $120 \mathrm{~m}$ were collected on 27 April 2016. Samples were kept at in situ temperature in 132 the dark until further processing.

Furthermore, surface samples from different other lakes were collected only once to 134 verify the recovery and performance of the HPLC-MS method on environmental samples of 135 different matrix composition. The following lakes were sampled: Hüttnersee (eutrophic, 658 
Polyamine variability and bacterial assimilation

136

137

138

139

140

141

142

143

144

145

m above sea level, area $0.165 \mathrm{~km}^{2}$, max. depth $13.3 \mathrm{~m}$, mean depth $6.3 \mathrm{~m}$, residence time 120 d, 47²1 ' N, $8^{\circ} 38^{\prime}$ E), Türlersee (mesotrophic, $643 \mathrm{~m}$ above sea level, area $0.497 \mathrm{~km}^{2}$, max. depth $22 \mathrm{~m}$, residence time $730 \mathrm{~d}, 47^{\circ} 16^{\prime} \mathrm{N}, 8^{\circ} 30^{\prime} \mathrm{E}$ ) (information obtained from Office of waste, water, energy and air, Canton Zurich, http://www.awel.zh.ch/internet/baudirektion/awel/de/wasser/messdaten/see_qualitaet.html).

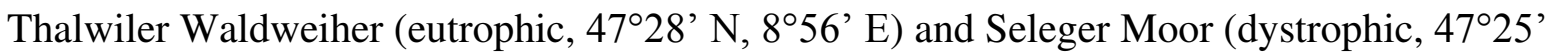
$\left.\mathrm{N}, 8^{\circ} 51^{\prime} \mathrm{E}\right)$.

\section{Ion-pairing liquid chromatography}

Polyamines were analyzed with an HPLC system (1260 Infinity series, Agilent Technologies) provided with a degasser, binary pump, autosampler and column oven. Analytes were separated on a YMC-Triart C-18 column ( 150 x $3 \mathrm{~mm}, 3 \mu \mathrm{m}$ particle size, YMC) at a flow rate of $500 \mu \mathrm{L} \mathrm{min}$. $^{-1}$ Solvent A (Milli-Q water) and solvent B (ACN) were amended with $0.1 \%$ HFBA and $2 \%$ PrA. Samples of $100 \mu \mathrm{L}$ and internal standard (Dah, final concentration $100 \mathrm{nM}$ ) were injected. A gradient elution started from 5\% B to 50\% B from 0 to 6 min, then $50 \% \mathrm{~B}$ was kept for $4.5 \mathrm{~min}$, then $50-70 \% \mathrm{~B}$ from 10.5 to $10.6 \mathrm{~min}$ and $70 \% \mathrm{~B}$ was maintained for $3.4 \mathrm{~min}$. Afterwards the gradient was returned from $70 \%$ to $5 \% \mathrm{~B}$ and column was re-equilibrated from 14.1 to $25 \mathrm{~min}$. Column was thermostated at $35^{\circ} \mathrm{C}$ and samples were kept at $4{ }^{\circ} \mathrm{C}$ during analyses. Prior to each measurement, column was equilibrated for $5 \mathrm{~min}$ at $95 \%$ A until the pressure was stable. Up to four blanks were run using the gradient elution above. Samples were amended with HFBA (final concentration 0.1 $\%)$ prior to HPLC-MS analyses.

Mass spectrometry 
Polyamine variability and bacterial assimilation

DFPA detection was carried out on an API 5000 triple quadrupole mass spectrometer

(AB Sciex) equipped with an electrospray ionization source and a QJet ion guide component.

During the multiple reaction monitoring scan (MRM) mode, polyamines were detected in the

positive ion mode. Tandem mass spectrometry (MS/MS) analyses were performed to select

164 for pairs of precursor and product ions (transitions) specific for each polyamine. Two

transitions with the highest signal intensity were selected per each analyte (only one

transition was used for Dap and Dah). Declustering potential (DP), entrance potential (EP),

collision energy $(\mathrm{CE})$ and cell exit potential (CXP) parameters were further optimized for each transition (Suppl. Table 2). EP was set for all transitions to $10 \mathrm{~V}$. The lower $\mathrm{m} / \mathrm{z}$ threshold for all scans was set to 25 . To optimize the ion source parameters, $0.1 \%$ HFBA and $100 \% \mathrm{ACN}$ were applied isocratically (50\%:50\%) at the flow rate of $500 \mu \mathrm{L} \mathrm{min}^{-1}$. Ion-spray 171 voltage (IS), temperature (TEM), along with curtain (CUR), collision (CAD) and ion source 172 gas (GS1 and GS2) parameters were optimized for highest signal intensities of the selected

173 transitions using the MRM scan mode. The outcome of the ion source optimization gave the 174 following setting: $\mathrm{IS}=1500 \mathrm{~V}, \mathrm{TEM}=700^{\circ} \mathrm{C}, \mathrm{CUR}=10, \mathrm{CAD}=10, \mathrm{GS} 1=50, \mathrm{GS} 2=60$.

175 Nitrogen was applied as curtain, collision and ion source gas. The dwell time was set to 100 ms for all transitions. Data was acquired with the software Analyst (version 1.6.1, AB Sciex) and quantified by the MultiQuant software (version 2.1, AB Sciex) using the corresponding 178 extracted ion chromatograms.

\section{Method precision, limits of detection and quantification}

A calibration curve was established for each polyamine transition using dilution series solution and the corresponding response factors were calculated using Dah as internal 
Polyamine variability and bacterial assimilation

184

standard. Prior to injection, dilution series of polyamine standards as well as environmental samples were spiked with internal standard to yield a final concentration of $10 \mathrm{nM}$. Thus, a constant internal standard concentration was maintained in all samples measured in this study. Limits of detection (LOD) and limits of quantification (LOQ) were determined from the calibration curves of the corresponding polyamine-transitions. LOD was determined as the lowest analyte concentration yielding the signal to noise ratio $>2$ after correction for blank. LOQ was determined as the lowest polyamine concentration yielding a relative standard deviation of $<10 \%$ obtained from the triplicate measurements. Method recovery was determined in duplicate samples from different lakes (Lake Zurich, Hüttnersee, Türlersee, Thalwiler Waldweiher, Seleger Moor) amended with ${ }^{13} \mathrm{C}$-labeled Put at a final concentration of $1 \mathrm{nM}$ and $10 \mathrm{nM}$ (Suppl. Table 3).

\section{Putrescine uptake and kinetics}

Triplicate samples amended with ${ }^{13} \mathrm{C}$-Put at a final concentration of $10 \mathrm{nM}$ and duplicated controls without labeled putrescine were incubated for 4 to $5 \mathrm{~h}$ in the dark at in situ temperature. Subsamples of $1 \mathrm{~mL}$ for quantification of DFPA by HPLC-MS taken at $1 \mathrm{~h}$ intervals were filtered into glass vials using IC Acrodisc filters $(0.2 \mu \mathrm{m}$, Pall $)$ and stored at $24^{\circ} \mathrm{C}$. This was repeated for each incubation experiment (I-V) (Table 1). In addition, a sample filtered through $0.8 \mu \mathrm{m}$ filter (Nuclepore, Sterico AG) was incubated in parallel on 6 July 2016 to determine a contribution of free-living bacteria to the total Put uptake. Put turnover time was calculated as the quotient of the total dissolved Put concentration and the uptake rate. Kinetics of Put uptake was investigated on 18 March 2016 in triplicates of 100 $\mathrm{mL}$ taken from the depth of $5 \mathrm{~m}$ that were spiked with ${ }^{13} \mathrm{C}$-Put to obtain final concentrations of 1, 2, 5, 10, 20, 50 and $100 \mathrm{nM}$. Uptake rate was derived from differences in Put 
Polyamine variability and bacterial assimilation

208

209

210

211

212

213

214

215

216

217

218

219

220

221

222

223

224

225

226

227

228

229

230

231

concentrations after $2 \mathrm{~h}$ of incubation. Influence of other compounds on Put uptake was studied in another experiment performed on 18 March 2016. Samples of $100 \mathrm{~mL}$ were spiked with ${ }^{13} \mathrm{C}$-Put (final concentration $\left.10 \mathrm{nM}\right)$ or with a mixture of ${ }^{13} \mathrm{C}$-Put $(10 \mathrm{nM})$ and either arginine, ornithine, or spermidine (100 nM each) (Table 1). The incubation period was $4 \mathrm{~h}$ and Put concentrations were quantified in $1 \mathrm{~h}$ intervals by LC-MS method described above. All incubations were performed at in situ temperatures in the dark. Samples were stored immediately after filtration at $-24^{\circ} \mathrm{C}$ until further measured.

\section{Putrescine incorporation}

For bulk incorporation rates triplicate samples of $10 \mathrm{~mL}$ were collected into sterile tubes and amended with $\left[1,4-{ }^{14} \mathrm{C}\right]$ putrescine $\left({ }^{14} \mathrm{C}\right.$-Put, specific activity $110 \mathrm{mCi} \mathrm{mmol}{ }^{-1}$, incubations I-II) and $\left[2,3-{ }^{3} \mathrm{H}\right]$ putrescine $\left({ }^{3} \mathrm{H}-\mathrm{Put}\right.$, specific activity $60 \mathrm{Ci} \mathrm{mmol}^{-1}$, incubations III-IV) from American radiolabeled chemicals to a final concentration of $10 \mathrm{nM}$. Duplicated controls prefixed with paraformaldehyde (PFA, final concentration 2\%) were run in parallel. We used Put labeled with two radioisotopes because (a) incorporation rates measured with ${ }^{14} \mathrm{C}$-tracer can be directly compared with total uptake rates measured with ${ }^{13} \mathrm{C}$-Put samples, and (b) ${ }^{3} \mathrm{H}$-tracer was found to be advantageous for microautoradiography analyses. All samples were incubated for $2 \mathrm{~h}$ in darkness at in situ temperature and subsequently fixed with PFA. Then, subsamples of $5 \mathrm{~mL}$ were filtered on $0.2 \mu \mathrm{m}$ nitrocellulose filters (GSWP, diameter, $25 \mathrm{~mm}$, Millipore) and processed as described by Kirchman (2001). Briefly, filters were washed twice with $5 \%$ ice-cold trichloroacetic acid and with $80 \%$ ice-cold ethanol to extract protein from microbial cells retained on a filter. Air-dried filters were placed into scintillation vials and dissolved in ethyl acetate. Afterwards scintillation cocktail (Rotoszint eco plus, LSC-Universalcocktail, Roth) was added and samples were analyzed with a 
Polyamine variability and bacterial assimilation

232

233

234

235

236

237

238

239

240

241

242

243

244

245

246

247

248

249

250

251

252

253

254

255

scintillation counter (Liquid Scintillation Analyzer, Tri-Carb 3170TR/SL, Perkin Elmer).

Radioactivity (as disintegrations per minute) measured in samples corresponded to the amount of Put incorporated into microbial biomass over time. Differences between Put uptake rate (measured with ${ }^{13} \mathrm{C}$-Put) and the corresponding incorporation rate (measured with ${ }^{14} \mathrm{C}$-Put and ${ }^{3} \mathrm{H}$-Put) were assumed to equal respiration (note that respiration was not directly measured). Put turnover time was calculated by dividing ${ }^{13} \mathrm{C}$-Put concentration corrected for a natural Put pool by the corresponding uptake rate.

\section{MAR-FISH}

Samples of $10 \mathrm{~mL}$ were incubated with ${ }^{14} \mathrm{C}-\mathrm{Put}(10 \mathrm{nM})$ or ${ }^{3} \mathrm{H}-\mathrm{Put}(10$ and $100 \mathrm{nM})$

for $2 \mathrm{~h}$ in the dark at in situ temperature and fixed as described for the bulk incorporation experiment. Then, the samples were filtered on $0.2 \mu \mathrm{m}$ polycarbonate filters (GTTP, $25 \mathrm{~mm}$ diameter, Millipore) and washed twice with $1 \mathrm{~mL}$ of sterile pre-filtered deionized Milli-Q water $(0.2 \mu \mathrm{m}$ polycarbonate syringe filter, Whatman). CARD-FISH was performed according to Sekar et al. (2003) with the modifications of Neuenschwander et al. (2015). The following oligonucleotide probes were used: EUB338 I-III for most Bacteria (Daims et al. 1999), ALF968 for most Alphaproteobacteria (ALF) (Amann et al. 1997) and BET42a for most Betaproteobacteria (BET) (Manz et al. 1992), acI-853 for the acI lineage of Actinobacteria (acI) (Warnecke et al. 2005), LD12-115 for freshwater SAR11 (LD12) (Neuenschwander et al. 2015), R-BT065 for members of the genus Limnohabitans (RBT) (Šimek et al. 2001), PnecC-445 for Polynucleobacter asymbioticus, P. duraque, P. yangtzensis, P. sinensis (Hahn et al. 2009, 2016), LimA-23S-1435 for the LimA cluster of Limnohabitans (LimA) (Shabarova et al. 2017), LD2_739 for Saprospiraceae (LD2) (Pernthaler et al. 2004) and Cyc715 for Cyclobacteriaceae (Cyc) (Eckert et al. 2012). 
Polyamine variability and bacterial assimilation

256

257

258

259

260

261

262

263

264

265

266

267

268

269

270

271

272

273

274

275

276

277

278

279

Afterwards microautoradiography (MAR) was performed according to Alonso and Pernthaler (2005) with modifications described by Salcher et. al. (2008). Slides with hybridized bacterial cells were coated with a NTB emulsion (Carestream) and exposed for 1.5 to $2.5 \mathrm{~d}$ in the dark (Table 1). Emulsion was developed and fixed following manufacturer`s recommendations. MAR was performed in incubations I and II, whereas MAR coupled with CARD-FISH was conducted in incubations III and IV (Table 1). MAR-FISH preparations were evaluated with an epifluorescence microscope (Zeiss Axio Imager.M1) equipped with an automated microscopic platform. The option with multisport autofocus was chosen to provide a better focus of the cell layer on the agarose surface. Image quality control was applied to sort out low-quality images (Zeder et al. 2010). Between 500 and 2000 DAPI-stained cells captured from 8-10 images were analyzed per sample.

\section{Results}

\section{Optimization of chromatographic conditions}

HFBA as well as other volatile perfluorinated organic acids are readily used as ionpairing reagents in reversed-phase chromatography to allow retention of polar analytes and to improve overall chromatographic performance (Kuhlmann et al. 1995; Gao et al. 2006;

Häkkinen et al. 2007). In agreement with a previous study (Häkkinen et al. 2007) we found that HFBA enabled better separation and retention of polyamines than other tested ionpairing agents (pentafluoropropionic and tridecafluoroheptanoic acid). Gradient elutions with different HFBA concentrations $(0.025,0.05,0.1$, and $0.5 \%)$ were performed and analyzed. The length and mode of the gradient elution was further optimized by investigating different re-equilibration times and concentrations of $\mathrm{ACN}$. We found that a linear $\mathrm{ACN}$ gradient with 0.1\% HFBA was optimal for polyamine detection (Suppl. Fig. 1a). 
Polyamine variability and bacterial assimilation

Unfortunately the addition of perfluorinated acids often induces signal suppression of

analytes during MS detection (Kuhlmann et al. 1995), as also observed in our method. This was substantially ameliorated by also adding propionic acid to both solvents according to previous reports (Kuhlmann et al. 1995; Häkkinen et al. 2007). The tested column showed markedly better separation performance if the elution started with $5 \% \mathrm{ACN}$, which was essential for obtaining symmetrical peak shapes and for reducing peak tailing or splitting. To ensure the stable chromatographic conditions and reproducible retention times between individual injections, the column was flushed with $70 \% \mathrm{ACN}$ after the elution of polyamines to remove contaminants followed by a re-equilibration time of $10.9 \mathrm{~min}$. Another key factor for improving the sensitivity of the method was the addition of HFBA (final concentration $0.1 \%$ ) to samples prior to the analysis. The signal intensities of the analytes further increased, thus making the detection of sub-nM concentrations possible (Suppl. Table 2). Using the optimized LC-MS method, all 7 tested polyamines could be detected within 8 min (Suppl.

Fig. 1a). Moreover, the co-eluting compounds $\mathrm{Spd} / \mathrm{Nsd}$ and ${ }^{12} \mathrm{C}-\mathrm{Put} /{ }^{13} \mathrm{C}-\mathrm{Put}$ could be unambiguously quantified by their specific pairs of precursor and product ions (transitions).

Detection limits, recovery and signal interferences

Limits of detection (LOD) ranged between $0.2-0.5 \mathrm{nM}$ and limits of quantification (LOQ) were between 0.5 - $5 \mathrm{nM}$ (Suppl. Table 2). The detector response was linear at the lower range of concentrations $(0.2-20 \mathrm{nM})$ for all tested polyamines, whereas a non-linear response was observed for Spd and Nsd at higher concentrations (50 - $100 \mathrm{nM})$, which was due to detector saturation (Suppl. Fig. 2). Recovery was determined as relative differences in the concentration of ${ }^{13} \mathrm{C}$-labeled putrescine spiked into samples from freshwater habitats of different trophy and matrix complexity (Lake Zurich, Hüttnersee, Türlersee, Thalwiler 
Polyamine variability and bacterial assimilation

304

Waldweiher and Seleger Moor) compared to signals obtained in Milli-Q water. Recovery varied between $90-124$ and $97-123 \%$ at 1 and $10 \mathrm{nM}$ levels, respectively (Suppl. Table

3). Tested polyamines revealed no major differences in signal intensities and background noise between the environmental samples, implying comparatively low detection limits.

There were no remarkable interferences between the individual transitions monitored simultaneously. However, due to the applied mode of separation, i.e. no direct interaction between the column matrix and polyamines, there were signal interferences (likely HFBA adducts) detected for Nsd, Spd and Spm in blank samples (Milli-Q water). Nevertheless, these interferences could be substantially reduced after the optimization of the gradient including the column flushing step after the elution was accomplished. Other polyamines Dap, Put, ${ }^{13} \mathrm{C}-\mathrm{Put}$ and Cad expressed low and stable background signal intensities in blanks.

\section{Concentrations of individual polyamines and their spatiotemporal distribution}

Total DFPA concentrations in Lake Zurich varied greatly between different periods of the season (Fig. 1a). DFPA concentrations were $<2 \mathrm{nM}$ in winter. The pool was dominated by Put, which was uniformly distributed throughout the water column with concentrations from $<0.5$ to $1.5 \mathrm{nM}$ (Fig. 1a). DFPA concentrations markedly increased in spring with the absolute maximum (11 nM) detected in April. Put and Nsd quantitatively dominated the DFPA pool. DFPA concentrations gradually decreased with depth, but there were still approximately $2 \mathrm{nM}$ detected in the depth of $100 \mathrm{~m}$ (Fig. 1b). In early summer the concentration pattern of the vertical profile was similar to that in spring, but Nsd was no longer detected in high quantities. Total DFPA concentrations increased to $6 \mathrm{nM}$ (Fig. 1b). In late summer, vertical variations in DFPA concentrations resembled those in winter with total concentrations $<2 \mathrm{nM}$ (Fig. 1b). In autumn, there was an increase in DFPA concentrations 
Polyamine variability and bacterial assimilation

328 (up to $6 \mathrm{nM}$ ) and Put was the dominant component of the polyamine pool. However, the

329 decrease in DFPA concentrations with depth was less pronounced than in summer since there

330 were approximately $3 \mathrm{nM}$ between 30 to $100 \mathrm{~m}$ (Fig. 1b). Overall, the spatio-temporal

331 variations of Put concentrations tightly coincided with the total DFPA concentrations during

332 the whole study period indicating that Put was the key polyamine in Lake Zurich.

Virtually the whole Chl $a$ pool during this sampling campaign was constituted by the

334 filamentous cyanobacterium Planktothrix rubescens with the maximum concentration of 30.3

$335 \mu \mathrm{g} \mathrm{Chl} a \mathrm{~L}^{-1}$ by the end of August (Fig. 2a). P. rubescens was stratified in the metalimnion

336 (approximately at $15 \mathrm{~m}$ ) between May and October (Fig. 2a) which was below the depth of

337 maximal DFPA concentrations (Fig. 1). The spatiotemporal distribution of P. rubescens

338 tightly coincided with the period of a stable thermal stratification. Concentrations of diatoms

339 were generally low with the maximum of $5.2 \mu \mathrm{g} \mathrm{Chl} a \mathrm{~L}^{-1}$ in the epilimnion recorded in June

340 (early-summer). Diatoms were also detected between April and mid-May (spring) and from

341 July to mid-August (late-summer) at concentrations of 3.4 and $2.9 \mu \mathrm{g} \mathrm{Chl} a \mathrm{~L}^{-1}$, respectively

342 (Fig. 2b). Total bacterial abundances ranged from 0.5 to $4.510^{6}$ cell $\mathrm{mL}^{-1}$ with a maximum

343 detected between mid-May and mid-June (Fig. 2c), which occurred just after periods of

344 elevated DFPA concentrations (Fig. 1a). Bacterial abundances were substantially higher in

345 the upper $20 \mathrm{~m}$ of the water column during stratification (mid-April to October).

Incubation experiments with labeled putrescine

Concentrations of labeled Put $\left({ }^{13} \mathrm{C}\right.$-Put $)$ non-linearly decreased in all short-term incubation experiments (I-V, Table 1), implying that the tracer was actively utilized by microbes (Fig. 3). Uptake rates varied between 3.2 and $5 \mathrm{nM} \mathrm{h}^{-1}$ within the initial incubation period (0-2 h) (Fig. 3a, 3b), while those at the end of the incubation $(2-5 \mathrm{~h})$ ranged from 0.3 
Polyamine variability and bacterial assimilation

352 to $1 \mathrm{nM} \mathrm{h}^{-1}$. The maximum Put uptake rate of $5 \mathrm{nM} \mathrm{h}^{-1}$ was detected on 6 July 2016

353 (incubation V) (Fig. 3c). Concentrations of non-labeled (natural) Put were mostly around 2

$354 \mathrm{nM}$ (incubation I-IV), while substantially elevated Put concentrations (12 nM) were found on

3556 July 2016 (incubation V). Natural Put concentrations remained virtually constant with only

356 minor changes $(0.4-1.5 \mathrm{nM})$ throughout the incubation periods (Fig. 3). Concentrations of

357 natural Put in treatments amended with labeled Put were indistinguishable from those in

358 controls without tracer additions and this was recorded in all incubations (Fig. 3). Total Put

359 incorporation rates, determined in parallel with the radiolabeled tracers, varied between 4 -

$36037 \mathrm{pM} \mathrm{h}^{-1}\left({ }^{3} \mathrm{H}\right.$-Put $)$ and $0.8-0.9 \mathrm{nM} \mathrm{h}^{-1}\left({ }^{14} \mathrm{C}\right.$-Put $)$ at the initial $(0-2 \mathrm{~h})$ incubation period.

361 Such a large discrepancy and the negligible ${ }^{3} \mathrm{H}$-Put incorporation rates $(<0.01 \%$ of the Put

362 uptake rates measured with ${ }^{13} \mathrm{C}$-Put) imply that ${ }^{3} \mathrm{H}$-Put incorporation rates were apparently

363 underestimated. This could be potentially explained by a different fate or loss of the ${ }^{3} \mathrm{H}-$ label

364 during incubations. In comparison, ${ }^{14} \mathrm{C}$-Put incorporation rates were $18-19 \%$ of the

365 corresponding uptake rates suggesting that Put was mostly respired (Table 2), which is in the

366 range of previously published values (Liu et al. 2015). Put turnover times varied between 2.4

$367-4.4 \mathrm{~h}$.

368 Uptake kinetics of putrescine were examined in another incubation experiment (18

369 March 2016) using ${ }^{13} \mathrm{C}$-Put. The ${ }^{13} \mathrm{C}$-Put uptake rate changed with Put concentration $(1-50$

$370 \mathrm{nM}$ ) according to a hyperbolic curve following the Michaelis-Menten kinetics (Johnson and

371 Goody 2011). Interestingly, the measured uptake rate at $100 \mathrm{nM}$ concentration was markedly

372 higher and it could not be fitted by the hyperbolic curve (Fig. 4a). The maximal uptake rate

$373\left(\mathrm{~V}_{\max }\right)$ and the half saturation constant $\left(\mathrm{K}_{\mathrm{m}}\right)$ were $6.1 \mathrm{nM} \mathrm{h}^{-1}$ and $10.9 \mathrm{nM}$ (Fig. 4b),

374 respectively. The effects of amino acids (Arg, Orn) and other polyamines (Spd) on the uptake

375 of Put were investigated in an experiment with epilimnetic water from Lake Zurich on 18 
Polyamine variability and bacterial assimilation

376

377

378

379

380

381

382

383

384

385

386

387

388

389

390

391

392

393

394

395

396

397

398

399

March 2016. Put concentrations decreased equally rapidly in treatments amended only with

Put or with a mixture of Put and either Arg or Orn (Fig. 5). In contrast, the uptake of Put was inhibited by the excess amount of Spd (Fig. 5).

\section{Identification of putrescine-incorporating cells}

Despite measurable incorporation rates obtained with ${ }^{14} \mathrm{C}$-Put in September 2015

(incubation I and II, Table 2), no cells with visible putrescine incorporation could be identified by MAR (data not shown). Therefore, ${ }^{3} \mathrm{H}$-Put was used in incubations III and IV where on average $11.3 \%$ of total DAPI-stained cells showed active Put incorporation (Fig.

6). The fraction of Put-incorporating cells was further identified by combining MAR with CARD-FISH (MAR-FISH, Figs. 6, 7). Both the acI lineage of Actinobacteria (acI) and the RBT lineage of the genus Limnohabitans (R-BT) revealed the highest percentage $(25-32 \%)$ of Put-incorporating cells (Fig. 6). Betaproteobacteria (BET) and the acI lineage of Actinobacteria (acI) were the most abundant bacterioplankton components except for the deep water sample $(120 \mathrm{~m})$ from 27 April 2016 which was entirely dominated by BET. R-BT formed a large fraction of BET at the surface samples $(5 \mathrm{~m})$ and it showed a higher percentage of Put-active cells than BET. In contrast, the LimA lineage of the genus Limnohabitans (LimA) with relative abundances of $3 \%$ revealed only a low fraction of Putincorporating cells (4-8\%). Alphaproteobacteria (ALF) was the minor component of the community (3-4 \%) but approximately $15 \%$ of ALF incorporated Put at the surface, which was higher than the community average (Fig. 6). On the other hand, nearly no ALF incorporated Put in the sample from $120 \mathrm{~m}$. Cyclobacteriaceae (Cyc) accounted for $4-8 \%$ of the assemblage and their proportions of Put-active cells varied between $6-13 \%$ (Fig. 6). Bacteria from other tested lineages such as the PnecC, LD12 and LD2 were found in very 
Polyamine variability and bacterial assimilation

400

401

402

403

404

405

low proportions $(<2 \%)$ and showed no visible Put incorporation (data not shown). In addition, Asterionella sp. (diatom) and P. rubescens (cyanobacterium) were also found to incorporate Put (Fig. 7e, h).

\section{Discussion}

\section{Detection of DFPA in freshwaters}

Our HPLC-MS method allowed direct detection of sub-nM concentrations of underivatized DFPA in diverse freshwater habitats at threshold concentrations that were comparable to or lower than previously reported ones (Nishibori 2001, 2003; Lu et al. 2014; Liu et al. 2015; Lu et al. 2015). The limits of detection of our method ranged between 0.05 $0.5 \mathrm{nM}$ (Suppl. Table 2), which is sufficiently sensitive for the accurate quantification of compounds at low to sub-nM levels in freshwater samples (Horňák and Pernthaler 2014; Horňák et al. 2016). Although Nsd and Spd could not be separated chromatographically, their unambiguous quantification was possible by mass spectrometry (MS) using the compoundspecific pairs of precursor and product ions (transitions, Suppl. Table. 2). MS detection could, moreover, distinguish between natural Put and its isotope-labeled analog thereby providing a significant advantage over conventional fluorescence or pulse-amperometric detectors. The method also allows for a higher throughput (of 3 samples per hour) than reported previously (Nishibori 2001; 2003; Lu et al. 2014) and only requires addition of the ion-pairing reagent to samples prior to analysis. Despite the latter, the tested column maintained very stable and reproducible chromatographic conditions with low levels of background signal, allowing for the processing of large quantities of environmental samples without deterioration of detection quality. 
Polyamine variability and bacterial assimilation

\section{Spatiotemporal variations of DFPA in Lake Zurich}

This study provides a first spatiotemporal characterization of DFPA concentrations in a natural freshwater system. The total DFPA concentrations in Lake Zurich are comparable with those in seawater (Nishibori 2001; Nishibori et al. 2003; Lu et al. 2014; Liu et al. 2015) and are substantially lower than in a eutrophic coastal salt pond (Lee and Jørgensen 1995). Put and Spd usually dominate in coastal seawater (Badini et al. 1994; Nishibori 2001), while other DFPA such as Nsd, Cad are reported only sporadically. This is in agreement with our data (Fig. 1b): Put represented the quantitatively most important DFPA in all depths of Lake Zurich throughout the study period, whereas Spm and Dap were consistently low (Fig. 1b). Elevated concentrations of Nsd were only observed during spring (Fig. 1b, 15 April). Similar to other polyamines, Nsd plays an improtant role in cell growth and development (Kusano et al. 2008). Nsd was previously detected in seawater during a bloom of the dinoflagellate Gymnodinium spp. (Nishibori et al. 2003). Members of this genus are also common in Lake Zurich (Posch et al. 2015). Nevertheless, since no systematic analyses of the exudates of different phytoplankton taxa were performed we can only speculate about the potential source of Nsd in our samples.

Put concentrations in a coastal salt pond followed the pattern of primary production (Lee and Jørgensen 1995), suggesting that actively photosynthesizing algae were the major source of DFPA. In our study, the concentrations of total DFPA increased markedly in spring (Fig. 1a), which coincided with increased diatom chl $a$ concentrations (Fig. 2a). Higher amounts of exudates are released during the spring phytoplankton bloom and these exudates are a known source of polyamines (Höfle 1984; Lu et al. 2014). In addition, HPLC-MS analyses confirmed the presence of large quantities of intracellular polyamines in cultures of planktonic diatoms (genera Gomphonema and Aulacoseira), including isolates from Lake 
Polyamine variability and bacterial assimilation

448

449

450

451

452

453

454

455

456

457

458

459

460

461

462

463

464

465

466

467

468

469

470

471

Zurich (Fragilaria sp.) (Suppl. Fig. 1b). Thus, it is likely that DFPA in our study system were at least partly derived from diatoms during spring.

However, the overall relationship between chl $a$ (and, in turn, primary production) and

DFPA concentrations in Lake Zurich appears to be more complex (Figs. 1, 2). The

filamentous cyanobacterium Planktothrix rubescens is the dominant primary producer in

Lake Zurich (Bossard et al. 2001; Garneau et al. 2015). It stratifies in the metalimnion (at approximately 12-15 m depth) from May to October (Fig. 2a) (Yankova et al. 2016) which is below the depth of maximal DFPA concentrations. This species releases only negligible amounts of extracellular products (Feuillade et al. 1990). It is, therefore, unlikely that DFPA originated from $P$. rubescens. However, the presence of diatoms cannot account for the increase in DFPA concentrations at the end of September (Figs. 1a, 2b), which might be related to heterotrophic processes such as protein degradation (Höfle 1984), grazing or cell lysis (e.g. Nagata 2000). On 9 April 2015 elevated DFPA concentrations of $\sim 2 \mathrm{nM}$ were found in the hypolimnion (Fig. 1a), contrasting with the low concentrations of $\sim 0.5 \mathrm{nM}$ in the remaining limnological year. This might be interpreted in the context of sedimentation of senescent phytoplankton cells from the epilimnion and their subsequent decomposition in deeper water layers (Grossart and Simon 1998).

\section{Uptake of labeled putrescine}

The concentration of ${ }^{13} \mathrm{C}$ - Put decreased non-linearly in all dark incubations (I-III and V) (Fig. 3), implying that the Put uptake rate decreased proportionally to the concentration of the tracer. These time-course changes in the uptake rate could be due to the upregulation of membrane transporters, but might also result from differences between microbial populations in the number of transporters and their respective saturation. Put uptake rates varied between 
Polyamine variability and bacterial assimilation

$4724.4-5 \mathrm{nM} \mathrm{h}^{-1}$ (incubations I, II, and V, Fig. 3) which is comparable to those in coastal

473 seawater, and higher than in open ocean waters (Liu et al. 2015). Concentrations of the tracer

474 substantially exceeded those of the natural Put in September 2015 (incubations I and II, Fig.

$4753 \mathrm{a}, \mathrm{b}$ ). Thus, our measurements reflected the potential (maximal) rather than the realized

476 uptake rates at that time point. By contrast, the concentrations of the labeled (tracer) and

477 natural Put were roughly equal in July 2016 (incubation V, Fig. 3c), suggesting that the

478 estimated Put uptake rate was likely close to the in situ one. Moreover, the concentration of

479 the natural Put pool remained stable over the course of the latter incubation, implying rapid

480 recycling (i.e., production) of this compound. Assuming that the natural and isotopically

481 labeled forms are consumed equally, the pool of dissolved Put at that time point was refilled

482 at a rate that was comparable to its uptake. Our detection method only targets dissolved free

483 polyamines (monomers) readily available to consumers. Therefore, despite stable

484 concentrations of ambient Put, it is unlikely that this Put pool was adsorbed to particles or

485 combined with other compounds which would preclude its consumption.

In September 2015 (incubations I and II, Table 2), approximately $20 \%$ of the Put-

487 derived $\mathrm{C}$ taken up by organisms (measured by the ${ }^{13} \mathrm{C}$-labeled tracer) was incorporated into

488 biomass (measured by the ${ }^{14} \mathrm{C}$-labeled tracer), which is lower than in coastal seawater (Liu et

489 al. 2015), and than the fraction of $\mathrm{C}$ that is typically assimilated from amino acids (Crawford

490 et al. 1974, Jørgensen et al. 1983, Simon and Tilzer 1987). In July 2016 (incubation V, Suppl.

491 Fig. 3), the Put uptake rate in the size fraction $<0.8 \mu \mathrm{m}$ was $66 \%$ of the total rate in unfiltered

492 lake water, indicating that a major proportion of Put was taken up by free-living bacteria.

493 This agrees with observations of the consumption of dissolved carbohydrates and amino

494 acids (Weiss and Simon 1999). Nevertheless, the different uptake rates in the filtered and raw

495 lake water indicate that also larger microorganisms or bacteria attached to particles 
Polyamine variability and bacterial assimilation

496

497

498

499

500

501

502

503

contributed to Put uptake. However, we caution that the filtration through a polycarbonate membrane resulted in a substantial loss in the concentration of natural Put, which might have caused a bias in our rate measurements (Suppl. Fig. 3). Despite this potential artifact our results nevertheless indicate that the planktonic microbes in Lake Zurich readily consumed Put, as has been reported for marine bacteria (Höfle 1984; Liu et al. 2015). This was, moreover, confirmed by direct microscopic observation (Figs. 6, 7a-d).

\section{Kinetics and inhibition of putrescine uptake}

To avoid a non-linear decrease in Put uptake velocity potentially caused by experimental bias (i.e., compositional changes of the microbial assemblage due to prolonged incubation time, arbitrary concentration of the tracer, or down-regulation of membrane transporters) we performed a short-term (2 h) experiment in March 2016 (incubation III, Fig. 4) with different Put concentrations ( $1-100 \mathrm{nM})$. The relationship between Put concentrations up to $50 \mathrm{nM}$ and uptake rate closely followed Michaelis-Menten kinetics (Johnson and Goody 2011) (Fig 4a). Therefore, Put uptake kinetics were similar to those of leucine and valine (Jørgensen 1992). By contrast, glucose consumption rates in Lake Zurich were constant at 10-30 nM concentrations (Horňák and Pernthaler 2014). In view of Put in situ concentrations $(<2 \mathrm{nM})$, the estimated maximum Put uptake rate $\left(V_{\max }\right)$ of $6.1 \mathrm{nM} \mathrm{h}^{-1}$ and the corresponding half-saturation constant $\left(\mathrm{K}_{\mathrm{m}}\right)$ of $10.9 \mathrm{nM}$ indicate that uptake rates in Lake Zurich were strongly limited by Put availability (Figs. 1, 4a). This corroborates previous reports on the kinetic parameters of amino acid uptake (Burnison and Morita 1974; Bertilsson et al. 2007). Put uptake rate furthermore increased linearly between $1-10 \mathrm{nM}$, demonstrating that bacteria rapidly responded to the realized concentration maxima of this substrate in the lake, as e.g. found in the epilimnion in April 2015 (Fig. 1). The Put uptake rate at the highest 
Polyamine variability and bacterial assimilation

520 offered concentration (100 nM) was approximately 2 times $\mathrm{V}_{\max }$ and thus significantly

521 deviated from the fitted hyperbolic curve (Fig. 3a). This discrepancy could be explained by

522 the results of our microautoradiographic analysis: the filamentous cyanobacterium $P$.

523 rubescens (6 $\mu \mathrm{g} \mathrm{Chl} a \mathrm{~L}^{-1}$ at $5 \mathrm{~m}$ depth in March 2016) was found to readily incorporate

524 radiolabeled Put at $100 \mathrm{nM}$ but not at $10 \mathrm{nM}$ (Figs. $7 \mathrm{~g}, \mathrm{~h}$ ).

525 The uptake of polyamines by bacteria is mainly mediated via a putrescine-specific

526 transport system and a second one that is preferential for spermidine (Tabor and Tabor 1985;

527 Mou et al. 2010). Besides external sources, bacteria can also synthesize Put (and in turn also

528 Spd) from arginine, ornithine or methionine (Tabor and Tabor 1984; 1985). Put uptake in $E$.

529 coli was significantly inhibited upon addition of other polyamines and amino acids (such as

530 ornithine), albeit at $\mu \mathrm{M}$ levels only (Tabor and Tabor 1966). Our competition assay with

531 natural plankton assemblage illustrates that the addition of Spd entirely suppressed

532 heterotrophic Put consumption, whereas the presence of both Put precursor amino acids

533 (ornithine and arginine) did not affect its uptake, as compared to the control amended with

534 Put only (Fig. 5). This confirms the presence of taxa harboring the spermidine-preferential

535 uptake system in the plankton of Lake Zurich, which corresponds with findings from marine

536 metatranscriptomes (Mou et al. 2011). Genes for the two major transport proteins were found

537 in many phyla such as for example Proteobacteria, Cyanobacteria or Actinobacteria (Mou et

538 al. 2010; Ghylin et al. 2014; Kurihara and Suzuki 2015). This suggests that numerous

539 microorganisms harbor multiple parallel transport systems to regulate the uptake of different

540 polyamines according to their actual availability, as reflected by our kinetic measurements

541 (Fig. 4). Our data also document that heterotrophs did not select against putrescine in the

542 presence of free amino acids suggesting a stable preference for polyamines. Moreover, a

543 rapid decrease (50\% over $5 \mathrm{~h}$ ) in the Spd concentration during the competition assay implies 
Polyamine variability and bacterial assimilation

544 that the heterotrophic Spd uptake rate is comparable to that of Put. However, the negligible

545 Spd concentrations in Lake Zurich likely limit its importance to bacterioplankton consumers, 546 as previously reported for $\mathrm{N}$-acetylglucosamine (Horňák and Pernthaler 2014).

Identification of Put incorporating cells

549 Despite measurable incorporation rates obtained with ${ }^{14} \mathrm{C}$-Put (incubations I and II,

550 Table 2), no cells with visible Put assimilation could be detected by MAR (data not shown).

551 Thus, additional MAR analyses were performed using ${ }^{3} \mathrm{H}-\mathrm{Put}$, which yielded a specific MAR

552 signal clearly distinguishable from the negative controls. This discrepancy might be due to

553 the higher specific activity of the ${ }^{3} \mathrm{H}$-labeled tracer $\left(60 \mathrm{Ci} \mathrm{mmol}^{-1}\right)$ compared to the ${ }^{14} \mathrm{C}$ label

$554\left(110 \mathrm{mCi} \mathrm{mmol}^{-1}\right)$, likely resulting in a higher amount of silver grains in the near vicinity of 555 cells (Fig. 7).

Using MAR combined with CARD-FISH (Alonso and Pernthaler 2005) we provide

557 first direct evidence of Put assimilation at $10 \mathrm{nM}$ concentration by different groups of

558 freshwater bacterioplankton (Figs. 6, 7). Moreover, the summed abundances of the individual

559 taxa of Put incorporating bacteria corresponded well to the fraction of all DAPI-stained

560 bacteria with positive MAR signals (11\%), indicating that we successfully identified the

561 large majority of Put assimilating planktonic bacteria. The highest fractions $(20-30 \%)$ of

562 Put incorporating cells were affiliated with the acI lineage of Actinobacteria and with

563 Betaproteobacteria, notably the R-BT lineage of the genus Limnohabitans (Fig. 6b). In

564 comparison, only $4-7 \%$ of bacteria affiliated with the recently described LimA cluster of

565 the genus Limnohabitans (Shabarova et al. 2017) incorporated Put. The bacterioplankton

566 assemblage of Lake Zurich during the growing season is numerically dominated by

567 Actinobacteria and Betaproteobacteria (Salcher et al. 2008, 2013; Eckert et al. 2012), which 
Polyamine variability and bacterial assimilation

568 further emphasizes the quantitative importance of these groups as Put consumers. Our results 569 confirm the consumption of Put by members of the acI lineage of Actinobacteria, as 570 hypothesized from the reconstruction of the respective metabolic pathway in single-cell 571 amplified genomes (Ghylin et al. 2014). Genome sequences of Limnohabitans planktonicus 572 (Kasalický et al. 2010) and other Limnohabitans isolates (Zeng et al., 2012) also indicate the 573 presence of polyamine transporters. In contrast, no such uptake mechanism was found in 574 members of the Polynucleobacter-C cluster (Hahn et al. 2009, 2016) which agrees with our 575 MAR analyses. This points at differences in substrate preferences between these sympatric 576 betaproteobacterial lineages, as has been shown before for other labile DOC compounds 577 (Salcher et al. 2013). Other epilimnetic populations with fractions of active cells above the 578 community average (11\%) were affiliated with Cyclobacteriaceae and Alphaproteobacteria 579 (Fig. 6b). However, the common freshwater alphaproteobacterial LD12 lineage (Salcher et al. 580 2011) did not show positive MAR signals, which may reflect their suggested oligotrophic 581 lifestyle. Therefore, lower Put concentrations (e.g. $1 \mathrm{nM}$ ) or longer incubation times should 582 be tested to confirm the MAR results of our study. The planktonic diatom Asterionella sp. and the cyanobacterium P. rubescens 584 incorporated Put at 10 and $100 \mathrm{nM}$ concentrations, respectively (Fig. 7e, h). This agrees with 585 previous reports on the uptake of diverse monomers by $P$. rubescens (e.g.: Zotina et al. 2003) 586 and diatoms (Tuchman et al. 2006), by which these primarily phototrophic organisms may 587 satisfy significant fractions of their nitrogen and carbon demands. In Asterionella sp., the 588 number of silver grains, which is roughly proportional to the amount of assimilated Put 589 (Horňák et al., 2012), visibly increased at 100 nM (Fig. 7f) suggesting a concentration590 dependent Put incorporation. It remains to be investigated whether diatoms can also 591 assimilate Put at the low ambient concentrations $(<2 \mathrm{nM})$ that are more frequently 
Polyamine variability and bacterial assimilation

592

593

594

595

596

597

598

599

600

601

602

603

604

605

606

607

608

609

610

611

612

613

614

615

616

617

618

619

620

621

encountered in Lake Zurich. Finally, several bacterial taxa in the hypolimnion showed a comparable potential for Put assimilation (Fig. 6), even though the in situ concentrations of this substrate were much lower than in the epilimnion (Fig 1). As in the case of Spd incorporation this again demonstrates a "preparadness" of bacterioplankton populations to utilize a substrate despite its apparent rarity.

\section{References}

Alonso, C., and J. Pernthaler. 2005. Incorporation of glucose under anoxic conditions by bacterioplankton from coastal North Sea surface waters. Appl. Environ. Microbiol. 71: 1709-1716. doi:10.1128/aem.71.4.1709-1716.2005

Amann, R., F.-O. Glöckner, and A. Neef. 1997. Modern methods in subsurface microbiology: in situ identification of microorganisms with nucleic acid probes. FEMS Microbiol. Rev. 20: 191-200. doi:10.1111/j.1574-6976.1997.tb00308.x

Badini, L., R. Pistocchi, and N. Bagni. 1994. Polyamine transport in the seaweed Ulva rigida (Chlorophyta). J. Phycol. 30: 599-605. doi:10.1111/j.0022-3646.1994.00599.x

Bertilsson, S., A. Eiler, A. Nordqvist, and N. O. G. Jørgensen. 2007. Links between bacterial production, amino-acid utilization and community composition in productive lakes. ISME J. 1: 532-544. doi:10.1038/ismej.2007.64

Beutler, M., K. H. Wiltshire, B. Meyer, C. Moldaenke, C. Luring, M. Meyerhofer, U. P. Hansen, and H. Dau. 2002. A fluorometric method for the differentiation of algal populations in vivo and in situ. Photosynth. Res. 72: 39-53. doi:10.1023/a:1016026607048

Bossard, P., S. Gammeter, C. Lehmann, F. Schanz, R. Bachofen, H. R. Burgi, D. Steiner, and U. Zimmermann. 2001. Limnological description of the Lakes Zurich, Lucerne, and Cadagno. Aquat. Sci. 63: 225-249. doi:10.1007/PL00001353

Burnison, B. K., and R. Y. Morita. 1974. Heterotrophic potential for amino acid uptake in a naturally eutrophic lake. Appl. Microbiol. 27: 488-495.

Crawford, C. C., J. E. Hobbie, and K. L. Webb. 1974. The utilization of dissolved free amino acids by estuarine microorganisms. Ecology 55: 551-563. doi:10.2307/1935146

Daims, H., A. Bruhl, R. Amann, K. H. Schleifer, and M. Wagner. 1999. The domain-specific 
Polyamine variability and bacterial assimilation

probe EUB338 is insufficient for the detection of all bacteria: development and evaluation of a more comprehensive probe set. Syst. Appl. Microbiol. 22: 434-444. doi:10.1016/S0723-2020(99)80053-8

Eckert, E. M., M. M. Salcher, T. Posch, B. Eugster, and J. Pernthaler. 2012. Rapid successions affect microbial $\mathrm{N}$-acetyl-glucosamine uptake patterns during a lacustrine spring phytoplankton bloom. Environ. Microbiol. 14: 794-806. doi:10.1111/j.14622920.2011.02639.x

Feuillade, M., J. Feuillade, and V. Fiala. 1990. The effect of light on the release of organic compounds by the cyanobacterium Oscillatoria rubescens. Aquat. Sci. 52: 345-359. doi:10.1007/BF00879762

Gao, S., S. Bhoopathy, Z.-P. Zhang, D. S. Wright, R. Jenkins, and H. T. Karnes. 2006. Evaluation of volatile ion-pair reagents for the liquid chromatography-mass spectrometry analysis of polar compounds and its application to the determination of methadone in human plasma. J. Pharm. Biomed. Anal. 40: 679-688. doi:http://dx.doi.org/10.1016/j.jpba.2005.05.022

Garneau, M.-È., T. Posch, and J. Pernthaler. 2015. Seasonal patterns of microcystinproducing and non-producing Planktothrix rubescens genotypes in a deep pre-alpine lake. Harmful Algae 50: 21-31. doi:10.1016/j.hal.2015.10.001

Ghylin, T. W., S. L. Garcia, F. Moya, and others. 2014. Comparative single-cell genomics reveals potential ecological niches for the freshwater acI Actinobacteria lineage. ISME J. 8: 2503-2516. doi:10.1038/ismej.2014.135

Gosetti, F., E. Mazzucco, V. Gianotti, S. Polati, and M. C. Gennaro. 2007. High performance liquid chromatography/tandem mass spectrometry determination of biogenic amines in typical Piedmont cheeses. J. Chromatogr. A 1149: 151-157. doi:http://dx.doi.org/10.1016/j.chroma.2007.02.097

Gosetti, F., E. Mazzucco, M. C. Gennaro, and E. Marengo. 2013. Simultaneous determination of sixteen underivatized biogenic amines in human urine by HPLC-MS/MS. Anal. Bioanal. Chem. 405: 907-916. doi:10.1007/s00216-012-6269-z

Grossart, H., and M. Simon. 1998. Bacterial colonization and microbial decomposition of limnetic organic aggregates (lake snow). Aquat. Microb. Ecol. 15: 127-140. doi:10.3354/ame015127 
Polyamine variability and bacterial assimilation

653

654

655

656

657

658

659

660

661

662

663

664

665

666

667

668

669

670

671

672

673

674

675

676

677

678

679

680

681

682

683

Hahn, M. W., E. Lang, U. Brandt, Q. L. Wu, and T. Scheuerl. 2009. Emended description of the genus Polynucleobacter and the species $P$. necessarius and proposal of two subspecies, $P$. necessarius subspecies necessarius subsp. nov. and $P$. necessarius subspecies asymbioticus subsp. nov. Int. J. Syst. Evol. Microbiol. 59: 2002-2009. doi: 10.1099/ijs.0.005801-0

Hahn, M. W., J. Jezberová, U. Koll, T. Saueressig-Beck, and J. Schmidt. 2016. Complete ecological isolation and cryptic diversity in Polynucleobacter bacteria not resolved by 16S rRNA gene sequences. ISME J. 10: 1642-1655. doi:10.1038/ismej.2015.237

Häkkinen, M. R., T. A. Keinänen, J. Vepsäläinen, A. R. Khomutov, L. Alhonen, J. Jänne, and S. Auriola. 2007. Analysis of underivatized polyamines by reversed phase liquid chromatography with electrospray tandem mass spectrometry. J. Pharm. Biomed. Anal. 45: 625-634. doi:10.1016/j.jpba.2007.09.001

Häkkinen, M. R., A. Roine, S. Auriola, and others. 2013. Analysis of free, mono- and diacetylated polyamines from human urine by LC-MS/MS. J. Chromatogr. B-Analytical Technol. Biomed. Life Sci. 941: 81-89. doi:10.1016/j.jchromb.2013.10.009

Hamana, K., and S. Matsuzaki. 1982. Widespread occurrence of norspermidine and norspermine in eukaryotic algae. J. Biochem. 91: 1321-1328.

Hamana, K., and S. Matsuzaki. 1992. Polyamines as a chemotaxonomic marker in bacterial systematics. Crit. Rev. Microbiol. 18: 261-283. doi:10.3109/10408419209113518

Höfle, M. G. 1984. Degradation of putrescine and cadaverine in seawater cultures by marine bacteria. Appl. Environ. Microbiol. 47: 843-849.

Hornák, K., M. Zeder, J.F. Blom, T. Posch, and J. Pernthaler. 2012. Suboptimal light conditions negatively affect the heterotrophy of Planktothrix rubescens but are beneficial for accompanying Limnohabitans spp. Environ. Microbiol. 14: 765-778. doi:10.1111/j.1462-2920.2011.02635.x

Horňák, K., and J. Pernthaler. 2014. A novel ion-exclusion chromatography-mass spectrometry method to measure concentrations and cycling rates of carbohydrates and amino sugars in freshwaters. J. Chromatogr. A 1365: 115-123. doi:10.1016/j.chroma.2014.09.007

Horňák, K., H. Schmidheiny, and J. Pernthaler. 2016. High-throughput determination of dissolved free amino acids in unconcentrated freshwater by ion-pairing liquid 
Polyamine variability and bacterial assimilation

684

685

686

687

688

689

690

691

692

693

694

695

696

697

698

699

700

701

702

703

704

705

706

707

708

709

710

711

712

713

714

chromatography and mass spectrometry. J. Chromatogr. A 1440: 85-93.

doi:10.1016/j.chroma.2016.02.045

Igarashi, K., and K. Kashiwagi. 1999. Polyamine transport in bacteria and yeast. Biochem. J. 344: 633-642. doi:10.1042/0264-6021:3440633

Igarashi, K., and K. Kashiwagi. 2000. Polyamines: Mysterious modulators of cellular functions. Biochem. Biophys. Res. Commun. 271: 559-564.

doi:10.1006/bbrc.2000.2601

Jantaro, S., P. Maenpaa, P. Mulo, and A. Incharoensakdi. 2003. Content and biosynthesis of polyamines in salt and osmotically stressed cells of Synechocystis sp. PCC 6803. FEMS Microbiol. Lett. 228: 129-135. doi:10.1016/S0378-1097(03)00747-X

Johnson, K. A., and R. S. Goody. 2011. The original Michaelis constant: Translation of the 1913 Michaelis-Menten paper. Biochemistry 50: 8264-8269. doi:10.1021/bi201284u

Jørgensen, N. O. G., M. Sondergaard, H. J. Hansen, S. Bosselmann, and B. Riemann 1983. Diel variation in concentration, assimilation and respiration of dissolved free amino acids in relation to primary and secondary production in two eutrophic lakes. Hydrobiologia 107: 107-122. doi:10.1007/BF00017426

Jørgensen, N. O. G. 1992. Incorporation of [3H] leucine and [3H] valine into protein of freshwater bacteria: field applications. Appl. Environ. Microbiol. 58: 3647-3653.

Kasalický, V., J. Jezbera, K. Šimek, and M. W. Hahn. 2010. Limnohabitans planktonicus sp. nov. and Limnohabitans parvus sp. nov., planktonic betaproteobacteria isolated from a freshwater reservoir, and emended description of the genus Limnohabitans. Int. J. Syst. Evol. Microbiol. 60: 2710-2714. doi: 10.1099/ijs.0.018952-0

Kirchman, D. 2001. Measuring bacterial biomass production and growth rates from leucine incorporation in natural aquatic environments. Methods Microbiol. 30: 227-237. doi:10.1016/s0580-9517(01)30047-8

Kuhlmann, F. E., A. Apffel, S. M. Fischer, G. Goldberg, and P. C. Goodley. 1995. Signal enhancement for gradient reverse-phase high-performance liquid chromatography electrospray ionization mass spectrometry analysis with trifluoroacetic and other strong acid modifiers by postcolumn addition of propionic acid and isopropanol. J. Am. Soc. Mass Spectrom. 6: 1221-1225. doi:10.1016/1044-0305(95)00571-4

Kurihara, S.; Suzuki, H. 2015. Recent advances in bacterial polyamine transport systems, p. 
Polyamine variability and bacterial assimilation

715

716

717

718

719

720

721

722

723

724

725

726

727

728

729

730

731

732

733

734

735

736

737

738

739

740

741

742

743

744

745

171-178. In H. Kusano and T. Suzuki [eds.], Polyamines: a universal molecular nexus for growth, survival, and specialized metabolism. Springer.

Kusano, T., T. Berberich, C. Tateda, and Y. Takahashi. 2008. Polyamines: essential factors for growth and survival. Planta 228: 367-381. doi:10.1007/s00425-008-0772-7

Lee, C., and N. O. G. Jørgensen. 1995. Seasonal cycling of putrescine and amino-acids in relation to biological production in a stratified coastal salt pond. Biogeochemistry 29: 131-157.

Liu, Q., X. Lu, B. B. Tolar, X. Mou, and J. T. Hollibaugh. 2015. Concentrations, turnover rates and fluxes of polyamines in coastal waters of the South Atlantic Bight. Biogeochemistry 123: 117-133.

Lu, X. X., L. Zou, C. Clevinger, Q. Liu, J. T. Hollibaugh, and X. Z. Mou. 2014. Temporal dynamics and depth variations of dissolved free amino acids and polyamines in coastal seawater determined by high-performance liquid chromatography. Mar. Chem. 163: 3644. doi:10.1016/j.marchem.2014.04.004

Lu, X., S. Sun, J. T. Hollibaugh, and X. Mou. 2015. Identification of polyamine-responsive bacterioplankton taxa in South Atlantic Bight. Environ. Microbiol. Rep. 7: 831-838. doi:10.1111/1758-2229.12311

Manz, W., R. Amann, W. Ludwig, M. Wagner, and K.-H. Schleifer. 1992. Phylogenetic oligodeoxynucleotide probes for the major subclasses of Proteobacteria: problems and solutions. Syst. Appl. Microbiol. 15: 593-600. doi:10.1016/S0723-2020(11)80121-9

Moran, M. A., R. Belas, M. A. Schell, and others. 2007. Ecological genomics of marine Roseobacters. Appl. Environ. Microbiol. 73: 4559-4569. doi:10.1128/AEM.02580-06

Mou, X., S. Sun, P. Rayapati, and M. Moran. 2010. Genes for transport and metabolism of spermidine in Ruegeria pomeroyi DSS-3 and other marine bacteria. Aquat. Microb. Ecol. 58: 311-321. doi:10.3354/ame01367

Mou, X. Z., M. Vila-Costa, S. L. Sun, W. D. Zhao, S. Sharma, and M. A. Moran. 2011. Metatranscriptomic signature of exogenous polyamine utilization by coastal bacterioplankton. Environ. Microbiol. Rep. 3: 798-806. doi:10.1111/j.17582229.2011.00289.x

Nagata, T. 2000. Production mechanisms of dissolved organic matter, p. 121-152. In D. L. Kirchman [ed.], Microbial ecology of the ocean. Wiley-Liss. 
Polyamine variability and bacterial assimilation

Neuenschwander, S. M., M. M. Salcher, and J. Pernthaler. 2015. Fluorescence in situ hybridization and sequential catalyzed reporter deposition (2C-FISH) for the flow cytometric sorting of freshwater ultramicrobacteria. Front. Microbiol. 6. doi:24710.3389/fmicb.2015.00247

Nishibori, N. 2001. Detection of free polyamine in coastal seawater using ion exchange chromatography. ICES J. Mar. Sci. 58: 1201-1207. doi:10.1006/jmsc.2001.1115

Nishibori, N., Y. Matuyama, T. Uchida, T. Moriyama, Y. Ogita, M. Oda, and H. Hirota. 2003. Spatial and temporal variations in free polyamine distributions in Uranouchi Inlet, Japan. Mar. Chem. 82: 307-314. doi:10.1016/s0304-4203(03)00076-8

Nishibori, N., and T. Nishijima. 2004. Changes in polyamine levels during growth of a redtide causing phytoplankton Chattonella antiqua (Raphidophyceae). Eur. J. Phycol. 39: 51-55. doi:10.1080/09670260310001636677

Nishibori, N., M. Niitsu, S. Fujihara, T. Sagara, S. Nishio, and I. Imai. 2009. Occurrence of the polyamines caldopentamine and homocaldopentamine in axenic cultures of the red tide flagellates Chattonella antiqua and Heterosigma akashiwo (Raphidophyceae). FEMS Microbiol. Lett. 298: 74-78. doi:10.1111/j.1574-6968.2009.01701.x

Pernthaler, J., E. Zollner, F. Warnecke, and K. Jürgens. 2004. Bloom of filamentous bacteria in a mesotrophic lake: identity and potential controlling mechanism. Appl. Environ. Microbiol. 70: 6272-6281. doi:10.1128/AEM.70.10.6272-6281.2004

Posch, T., B. Eugster, F. Pomati, J. Pernthaler, G. Pitsch, and E. Eckert. 2015. Network of interactions between ciliates and phytoplankton during spring. Front. Microbiol. 6: 1289. doi: 10.3389/fmicb.2015.01289

Salcher, M. M., J. Pernthaler, M. Zeder, R. Psenner, and T. Posch. 2008. Spatio-temporal niche separation of planktonic Betaproteobacteria in an oligo-mesotrophic lake. Environ. Microbiol. 10: 2074-2086. doi:10.1111/j.1462-2920.2008.01628.x

Salcher, M. M., J. Pernthaler, and T. Posch. 2011. Seasonal bloom dynamics and ecophysiology of the freshwater sister clade of SAR11 bacteria "that rule the waves" (LD12). ISME J. 5: 1242-1252. doi:10.1038/ismej.2011.8

Salcher, M. M., T. Posch, and J. Pernthaler. 2013. In situ substrate preferences of abundant bacterioplankton populations in a prealpine freshwater lake. ISME J. 7: 896-907. doi:10.1038/ismej.2012.162 
Polyamine variability and bacterial assimilation

777

778

779

780

781

782

783

784

785

786

787

788

789

790

791

792

793

794

795

796

797

798

799

800

801

802

803

804

805

806

807

Sekar, R., A. Pernthaler, J. Pernthaler, F. Warnecke, T. Posch, and R. Amann. 2003. An improved protocol for quantification of freshwater Actinobacteria by fluorescence in situ hybridization. Appl. Environ. Microbiol. 69: 2928-2935. doi:10.1128/AEm.69.5.2928-2935.2003

Shabarova, T., V. Kasalický, K. Šimek, J. Nedoma, P. Znachor, T. Posch, J. Pernthaler, and M. M. Salcher. 2017. Distribution and ecological preferences of the freshwater lineage LimA (genus Limnohabitans) revealed by a new double hybridisation approach. Environ. Microbiol. doi:10.1111/1462-2920.13663

Šimek, K., J. Pernthaler, M. G. Weinbauer, K. Horňák, J. R. Dolan, J. Nedoma, M. Mašín, and R. Amann. 2001. Changes in bacterial community composition and dynamics and viral mortality rates associated with enhanced flagellate grazing in a mesoeutrophic reservoir. Appl. Environ. Microbiol. 67: 2723-2733. doi:10.1128/AEM.67.6.27232733.2001

Simon, M., and M. M. Tilzer. 1987. Bacterial response to seasonal changes in primary production and phytopplankton biomass in Lake Constance. J. Plankt. Res. 9: 535-552. doi:org/10.1093/plankt/9.3.535

Sirocchi, V., G. Caprioli, M. Ricciutelli, S. Vittori, and G. Sagratini. 2014. Simultaneous determination of ten underivatized biogenic amines in meat by liquid chromatographytandem mass spectrometry (HPLC-MS/MS). J. Mass Spectrom. 49: 819-825. doi: $10.1002 / j m s .3418$

Tabor, C. W., and H. Tabor. 1966. Transport systems for 1,4-diaminobutane, spermidine, and spermine in Escherichia coli. J. Biol. Chem. 241: 3714-3723.

Tabor, C. W., and H. Tabor. 1984. Polyamines. Annu. Rev. Biochem. 53: 749-790. doi:10.1146/annurev.bi.53.070184.003533

Tabor, C. W., and H. Tabor. 1985. Polyamines in Microorganisms. Microbiol. Rev. 49: 8199.

Tuchman, N. C., M. A. Schollett, S. T. Rier, and P. Geddes. 2006. Differential heterotrophic utilization of organic compounds by diatoms and bacteria under light and dark conditions. Hydrobiologia 561: 167-177. doi:10.1007/s10750-005-1612-4

Warnecke, F., R. Sommaruga, R. Sekar, J. S. Hofer, and J. Pernthaler. 2005. Abundances, identity, and growth state of actinobacteria in mountain lakes of different UV 
Polyamine variability and bacterial assimilation

transparency. Appl. Environ. Microbiol. 71: 5551-5559. doi:10.1128/AEM.71.9.55515559.2005

Weiss, M., and M. Simon. 1999. Consumption of labile dissolved organic matter by limnetic bacterioplankton: the relative significance of amino acids and carbohydrates. Aquat. Microb. Ecol. 17: 1-12. doi:10.3354/ame017001

Yankova, Y., J. Villiger, J. Pernthaler, F. Schanz, and T. Posch. 2016. Prolongation, deepening and warming of the metalimnion change habitat conditions of the harmful filamentous cyanobacterium Planktothrix rubescens in a prealpine lake. Hydrobiologia 776: 125-138. doi:10.1007/s10750-016-2745-3

Zeder, M., E. Kohler, and J. Pernthaler. 2010. Automated quality assessment of autonomously acquired microscopic images of fluorescently stained bacteria. Cytometry. A 77: 76-85. doi:10.1002/cyto.a.20810

Zeng, Y., V. Kasalický, K. Šimek, and M. Koblížek. 2012. Genome sequences of two freshwater proteobacterial isolates, Limnohabitans species strains Rim28 and Rim47, indicate their capabilities as both photoautotrophs and ammonia oxidizers. J. Bacteriol. 194: 6302-6303. doi: 10.1128/JB.01481-12

Zotina, T., O. Köster, and F. Jüttner. 2003. Photoheterotrophy and light-dependent uptake of organic and organic nitrogenous compounds by Planktothrix rubescens under low irradiance. Freshw. Biol. 48: 1859-1872. doi:10.1046/j.1365-2427.2003.01134.x

\section{Acknowledgements:}

We thank E. Loher, D. Marty and T. Posch for their help with sampling, chlorophyll $a$ measurements and flow cytometry. Two anonymous reviewers and R. Howarth are acknowledged for their valuable comments on the earlier version of the manuscript. The study was supported by the Swiss National Science Foundation under the project 31003A163217. 
Polyamine variability and bacterial assimilation

\section{Figure Legends:}

835 Fig. 1: (a) Spatiotemporal distribution of total DFPA concentrations (nM) in Lake Zurich 836 from February to October 2015. (b) Concentrations of individual DFPA from one selected

837 sampling date in each season (indicated by vertical dashed lines) of 2015. Dap $=$

838 diaminopropane, Put = putrescine, $\mathrm{Spd}=$ spermidine, $\mathrm{Spm}=$ spermine, Nsd $=$ norspermidine

840 Fig. 2: Concentrations of (a) Planktothrix rubescens, (b) diatoms (both as $\mu \mathrm{g} \mathrm{Chl} a \mathrm{~L}^{-1}$ ), and 841 (c) total bacterial abundances $\left(10^{6}\right.$ cells $\left.\mathrm{mL}^{-1}\right)$ in the upper $25 \mathrm{~m}$ of Lake Zurich from 842 February to October 2015. Data is scaled to the maximum of the corresponding parameter.

844 Fig. 3: Temporal changes in concentrations of natural $\left({ }^{12} \mathrm{C}-\mathrm{Put}\right)$ and isotopically labeled 845 putrescine $\left({ }^{13} \mathrm{C}\right.$-Put) in selected incubation experiments (I, II, and V) conducted with 846 unfiltered epilimnetic samples (5 m) from Lake Zurich during September 2015 (a, b) and July 8472016 (c). Controls (Ctrl) that were not amended with ${ }^{13} \mathrm{C}$-Put show concentrations of natural 848 putrescine only. Values are means of triplicates. Error bars show standard deviations.

850 Fig. 4: (a) ${ }^{13} \mathrm{C}$-putrescine uptake rate as a function of its concentration in unfiltered samples 851 taken from Lake Zurich on 18 March 2016. The hyperbolic curve following the Michaelis852 Menten kinetics is fitted to data obtained from a $2 \mathrm{~h}$ incubation period. $\mathrm{V}_{\max }=$ maximum 853 uptake rate. $\mathrm{K}_{\mathrm{m}}=$ half saturation constant. Values are means of triplicates. Error bars show 854 relative standard deviations. (b) The corresponding double reciprocal (Lineweaver-Burk) 855 plot. 
Polyamine variability and bacterial assimilation

857 Fig. 5: Time-course of ${ }^{13} \mathrm{C}$-labeled putrescine $\left({ }^{13} \mathrm{C}\right.$-Put $)$ concentrations in eplimnetic samples 858 (5 m) collected on 18 March 2016. Samples were amended with ${ }^{13} \mathrm{C}$-Put or with a mixture of

$859{ }^{13} \mathrm{C}$-Put and either arginine (Arg), ornithine (Orn), and spermidine (Spd). Arg, Orn, and Spd 860 were added at $100 \mathrm{nM}$ each. Values are means of triplicates. Error bars show standard 861 deviations.

863 Fig. 6: (a) Relative abundances (as \% of DAPI-stained cells) and (b) fractions of cells with 864 visible putrescine incorporation (as \% of hybridized cells) affiliated with Betaproteobacteria 865 (BET), the R-BT lineage of the genus Limnohabitans (RBT); the LimA lineage of the genus 866 Limnohabitans (LimA), the acI lineage of Actinobacteria (acI), Alphaproteobacteria (ALF), 867 and Cyclobacteriaceae $(\mathrm{Cyc})$. Values are means of triplicates. Error bars show standard 868 deviations. A horizontal dashed line indicates the average Put incorporation (as \% of DAPI869 stained cells).

871 Fig. 7: Micrographs of cells assayed by MAR-FISH. Red colour indicates hybridized 872 bacterial cells (a-d) or chlorophyll $a$ autofluorescence (e-h) and blue colour DAPI-stained 873 cells. Active putrescine incorporation is indicated by dark silver grains in near vicinity of 874 cells. (a) acI lineage of Actinobacteria; (b) Betaproteobacteria, (c) Alphaproteobacteria; (d)

875 Cyclobacteriaceae, (e) diatom Asterionella sp. incubated with 10 and (f) $100 \mathrm{nM}{ }^{3} \mathrm{H}-$ 876 putrescine, (g) cyanobacterium Planktothrix rubescens incubated with 10 and (h) $100 \mathrm{nM}{ }^{3} \mathrm{H}-$ 877 putrescine. All bacteria were incubated with $10 \mathrm{nM}^{3} \mathrm{H}$-putrescine. Scale bars show $5 \mu \mathrm{m}$ (a878 d) and $50 \mu \mathrm{m}(\mathrm{e}-\mathrm{h})$, respectively. Images were adjusted for brightness, contrast and colour 879 saturation. 
Polyamine variability and bacterial assimilation

880

881

882

883

884

885

886

887

888

889

890

891

\section{Tables:}

Table 1: Overview of experimental incubations with stable isotope- and radiolabeled putrescine performed with samples from Lake Zurich during 2015-2016. Samples were taken from the depths of 5 and $120 \mathrm{~m}$ and incubated in triplicates for $2-5 \mathrm{~h}$ in the dark as unfiltered (raw) or after filtration $(<0.8 \mu \mathrm{m})$. Samples were amended with $10 \mathrm{nM}$ of either ${ }^{13} \mathrm{C}$ - or ${ }^{14} \mathrm{C} /{ }^{3} \mathrm{H}$-labeled putrescine. Additional samples spiked with variable concentrations of ${ }^{13} \mathrm{C}$ - $(1-$ $100 \mathrm{nM})$ or ${ }^{3} \mathrm{H}$-labeled putrescine $(10,100 \mathrm{nM})$ were incubated on 18 March 2016. Cells with visible putrescine incorporation were detected by microautoradiography (MAR) or by microautoradiography combined with CARD-FISH (MAR-FISH). MAR preparations were exposed for 1.5-2.5 days in the dark. *samples were incubated with putrescine $(10 \mathrm{nM})$ or with a mixture of putrescine $(10 \mathrm{nM})$ and either ornithine, arginine, and spermidine (100 nM each), nd - not determined 
Polyamine variability and bacterial assimilation

Table 1:

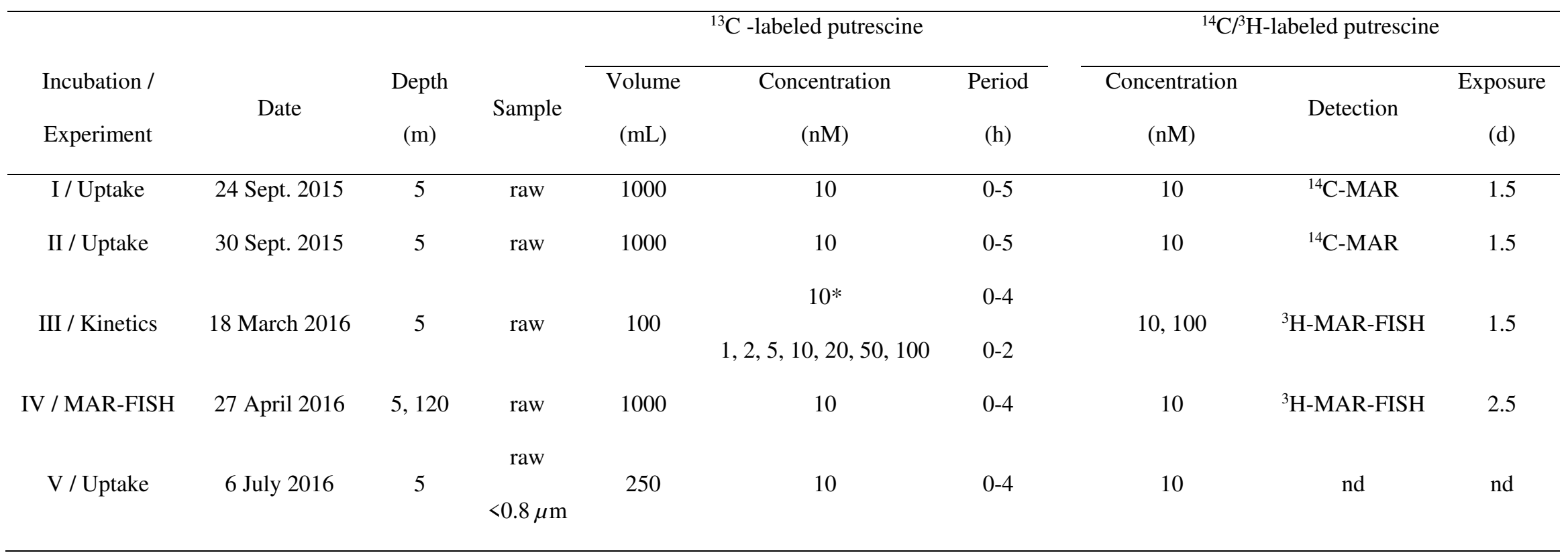


Polyamine variability and bacterial assimilation

892 Table 2: Putrescine in situ concentrations, uptake and incorporation rates, fractions of

893 incorporated putrescine and turnover times at the initial phase $(0-2 \mathrm{~h})$ of incubation

894 experiments. Note that putrescine incorporation rates were measured using ${ }^{14} \mathrm{C}$ - and ${ }^{3} \mathrm{H}$ -

895 labeled tracer in uptake experiments I-II and III-IV, respectively. *incorporation rates

896 measured with ${ }^{3} \mathrm{H}$-tracer; nd - not determined.

\begin{tabular}{ccccccc}
\hline $\begin{array}{c}\text { Incubation/ } \\
\text { Experiment }\end{array}$ & Date & $\begin{array}{c}\text { Concentration } \\
(\mathrm{nM})\end{array}$ & $\begin{array}{c}\text { Uptake rate } \\
\left(\mathrm{nM} \mathrm{h}^{-1}\right)\end{array}$ & $\begin{array}{c}\text { Incorporation } \\
\text { rate }\left(\mathrm{pM} \mathrm{h}^{-1}\right)\end{array}$ & $\begin{array}{c}\text { Incorporated } \\
\text { fraction (\%) }\end{array}$ & $\begin{array}{c}\text { Turnover } \\
\text { time (h) }\end{array}$ \\
\hline I / Uptake & 24 Sept. 2015 & 2.2 & 5.0 & 901.6 & 18 & 2.4 \\
II / Uptake & 30 Sept. 2015 & 2.8 & 4.4 & 825.7 & 19 & 2.9 \\
III / Kinetics & 18 March 2016 & 2 & 3.7 & $22^{*}$ & nd & 3.2 \\
IV / MAR-FISH & 27 April 2016 & $1.7(5 \mathrm{~m})$ & 3.2 & $15.5^{*}$ & nd & 3.7 \\
& & $0.5(120 \mathrm{~m})$ & 3.4 & $4.2^{*}$ & nd & 3 \\
V / Uptake & 6 July 2016 & $12(\mathrm{raw})$ & 5.0 & $36.7^{*}$ & nd & 4.4 \\
\hline
\end{tabular}


Polyamine variability and bacterial assimilation

\section{Figures:}

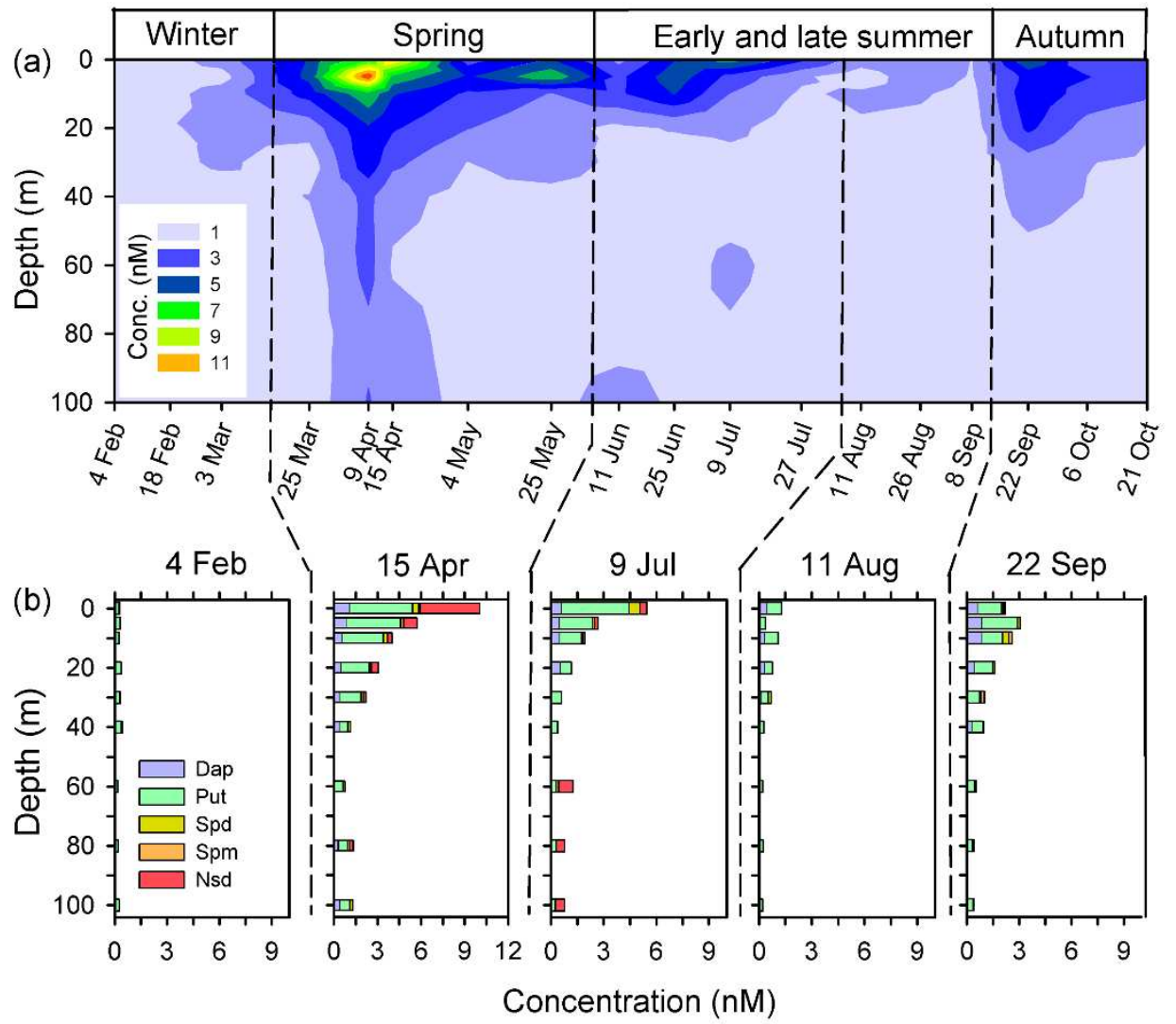

Fig. 1 

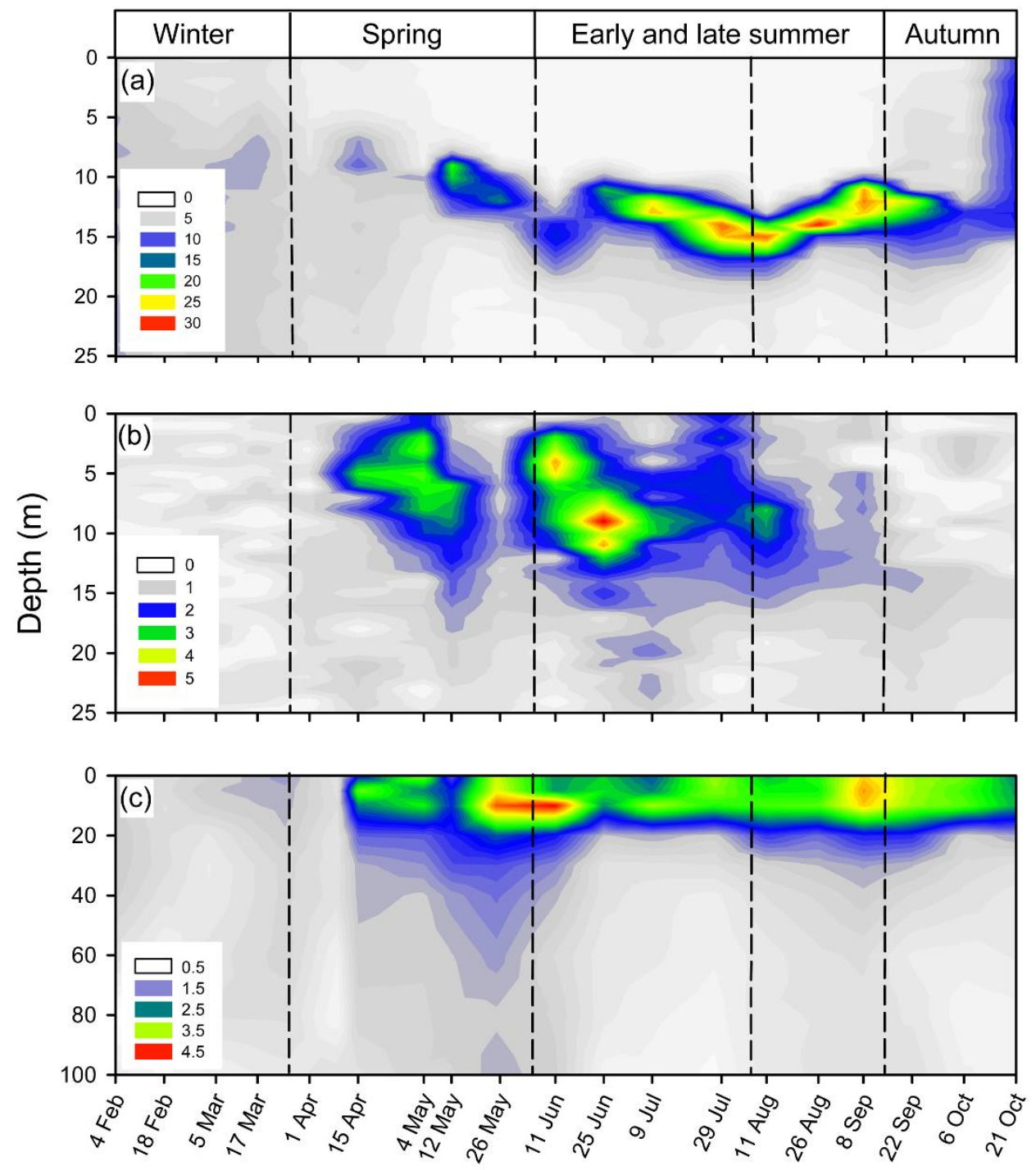

Fig. 2 
Polyamine variability and bacterial assimilation

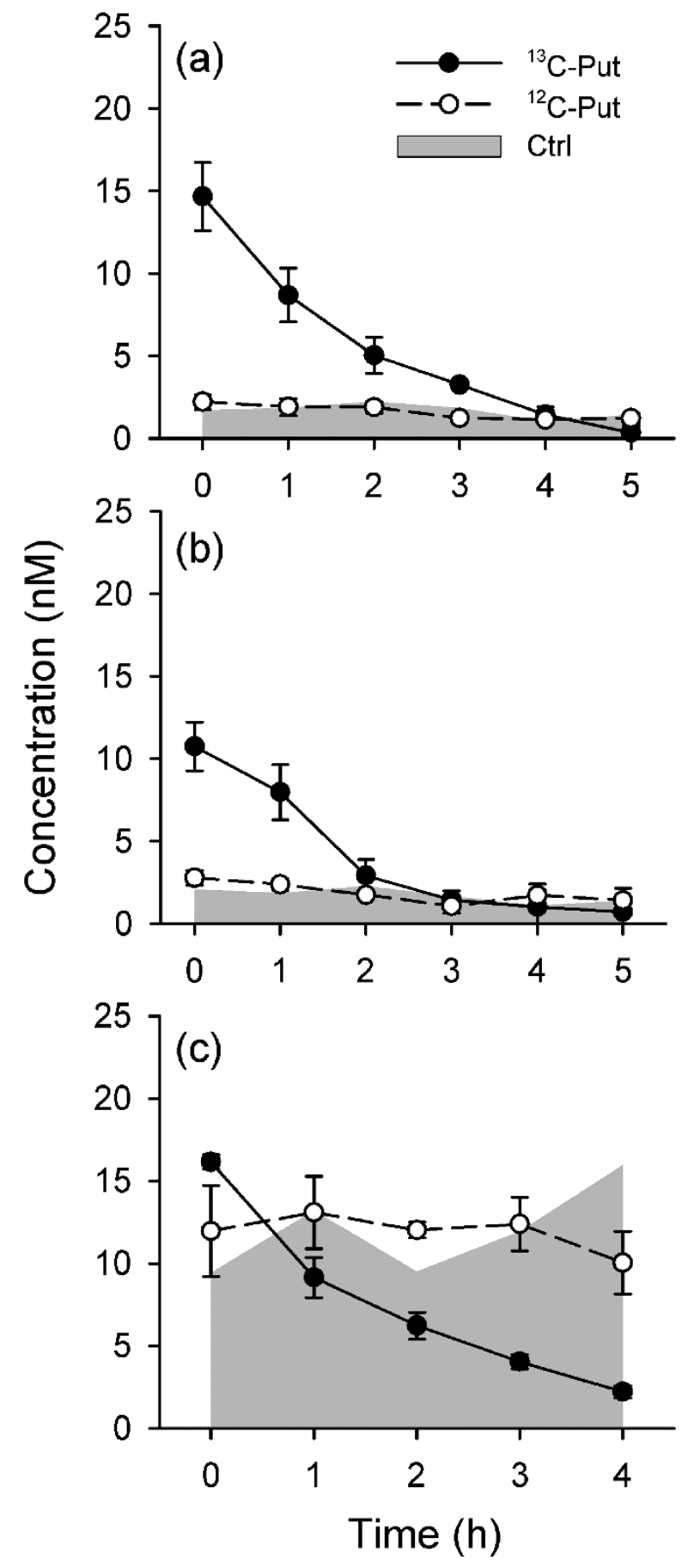

Fig. 3 
Polyamine variability and bacterial assimilation
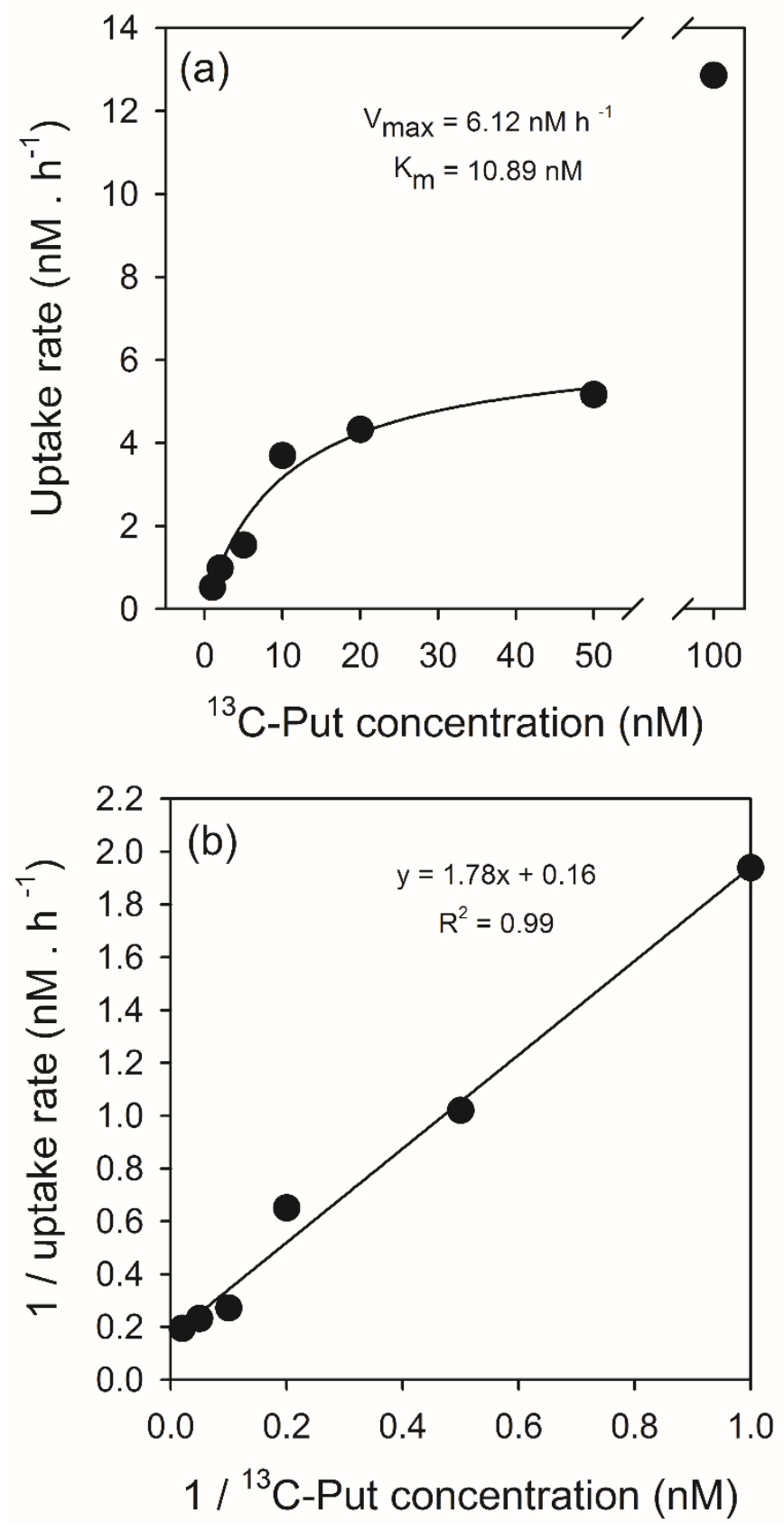

Fig. 4 
Polyamine variability and bacterial assimilation

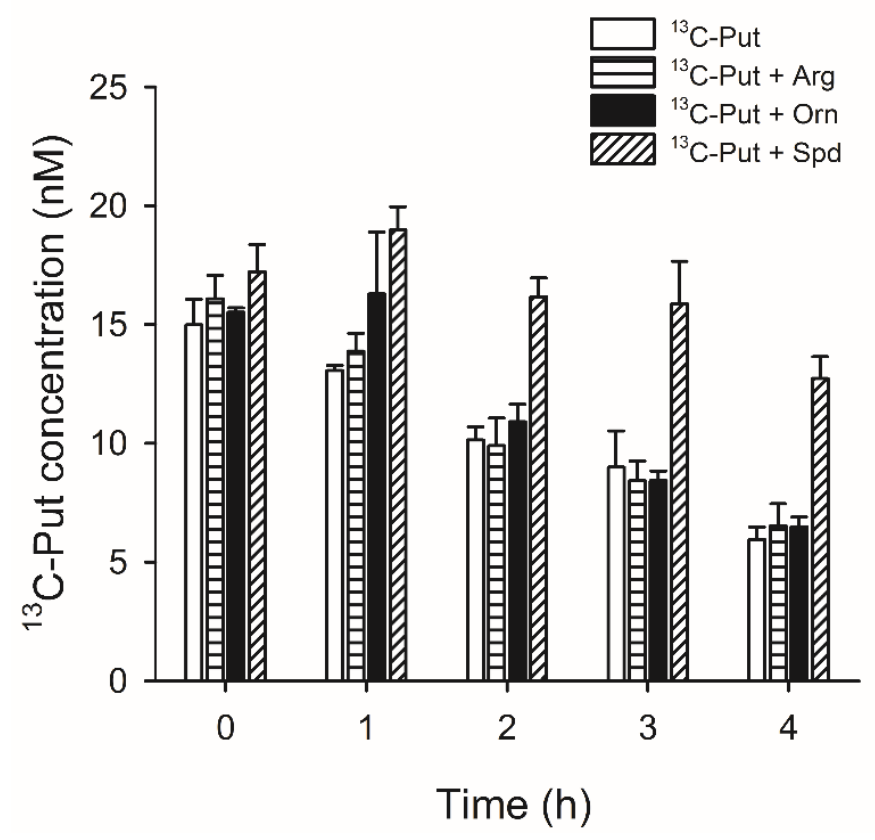

Fig. 5 
Polyamine variability and bacterial assimilation
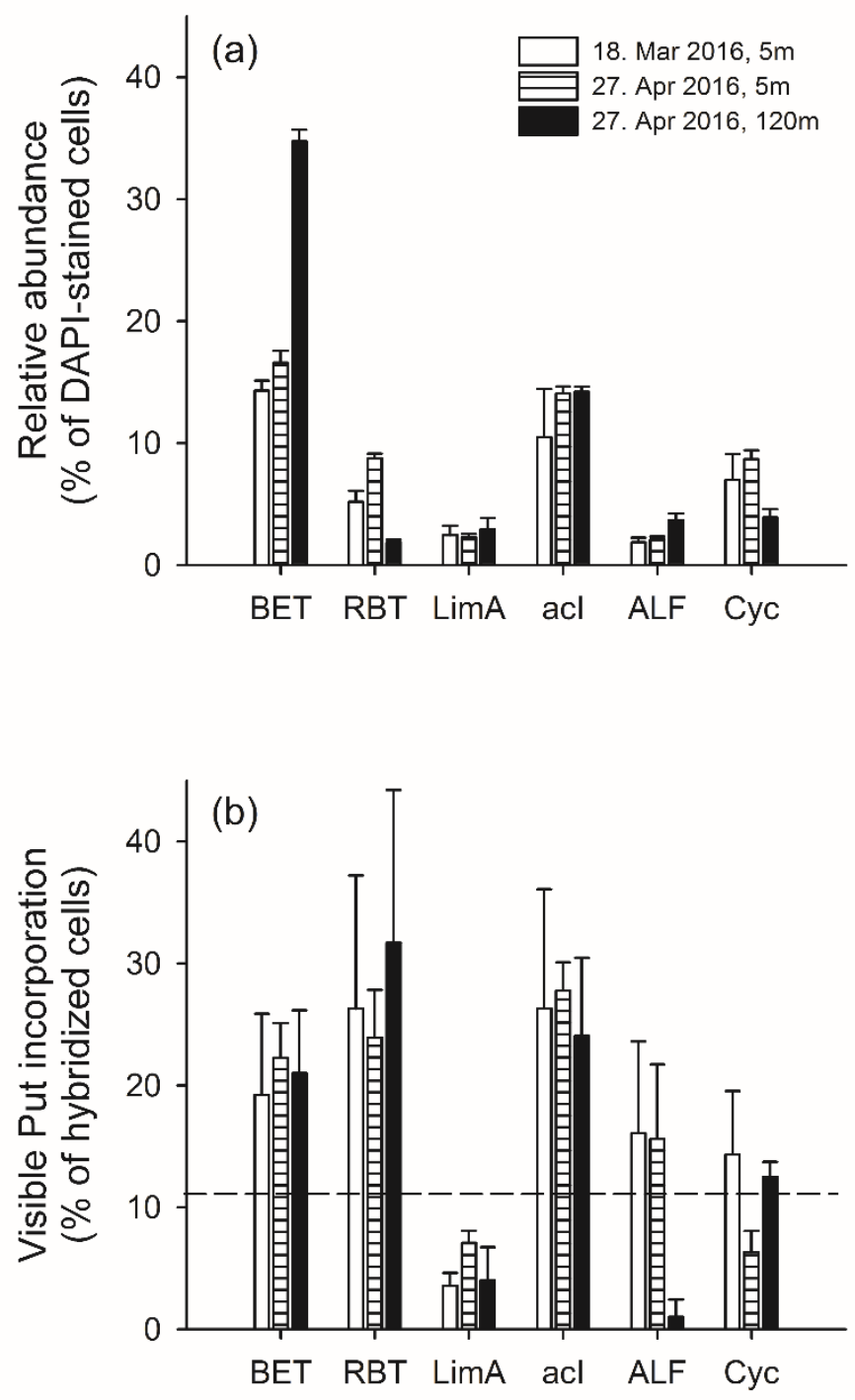

Fig. 6 
Polyamine variability and bacterial assimilation
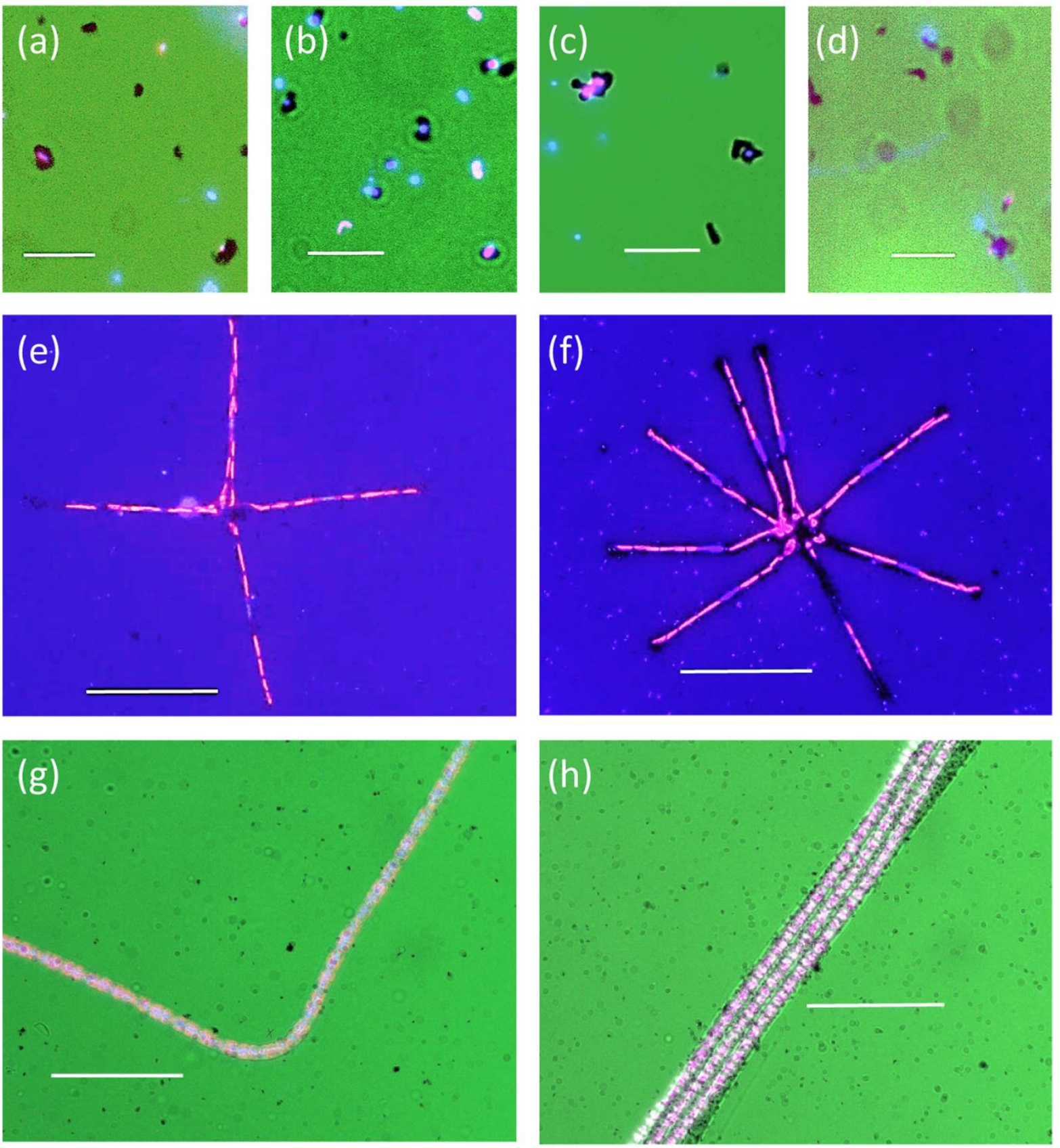

Fig. 7 
Polyamine variability and bacterial assimilation

\section{Supplemental Information}

Suppl. Table 1: Structures, formulas and molar masses of polyamines used in this study.

\begin{tabular}{|c|c|c|c|}
\hline Polyamine & Structure & Formula & Molar mass $\left(\mathrm{g} \mathrm{mol}^{-1}\right)$ \\
\hline diaminopropane & $\mathrm{H}_{2} \mathrm{~N}^{-}$ & $\mathrm{C}_{3} \mathrm{H}_{10} \mathrm{~N}_{2}$ & 74.13 \\
\hline putrescine & $\mathrm{H}_{2}$ & $\mathrm{C}_{4} \mathrm{H}_{12} \mathrm{~N}_{2}$ & 88.15 \\
\hline cadaverine & $\mathrm{H}_{2} \mathrm{~N}$ & $\mathrm{C}_{5} \mathrm{H}_{14} \mathrm{~N}_{2}$ & 102.18 \\
\hline diaminoheptane & $\mathrm{H}_{2}$ & $\mathrm{C}_{7} \mathrm{H}_{18} \mathrm{~N}_{2}$ & 130.23 \\
\hline norspermidine & $\mathrm{H}_{2}$ & $\mathrm{C}_{6} \mathrm{H}_{17} \mathrm{~N}_{3}$ & 131.22 \\
\hline spermidine & $\mathrm{H}_{2} \mathrm{~N}$ & $\mathrm{C}_{7} \mathrm{H}_{19} \mathrm{~N}_{3}$ & 145.25 \\
\hline spermine & & $\mathrm{C}_{10} \mathrm{H}_{26} \mathrm{~N}_{4}$ & 202.35 \\
\hline
\end{tabular}


Polyamine variability and bacterial assimilation

Suppl. Table 2: Mass spectrometry parameters for detection of polyamines. Transitions (pairs of precursor and product ions) and the corresponding declustering potential (DP), collision energy (CE), cell exit potential (CXP) parameters, limits of detection (LOD) and quantification $(\mathrm{LOQ})$. Dap $=$ diaminopentane, $\mathrm{Put}=$ putrescine, $\mathrm{Cad}=$ cadaverine, $\mathrm{Dah}=$ diaminoheptane, $\mathrm{Nsd}=$ norspermidine, $\mathrm{Spd}=$ spermidine, $\mathrm{Spm}=$ spermine, $\mathrm{IS}=$ internal standard. Transitions used for quantification are highlighted in bold. nd $=$ not determined

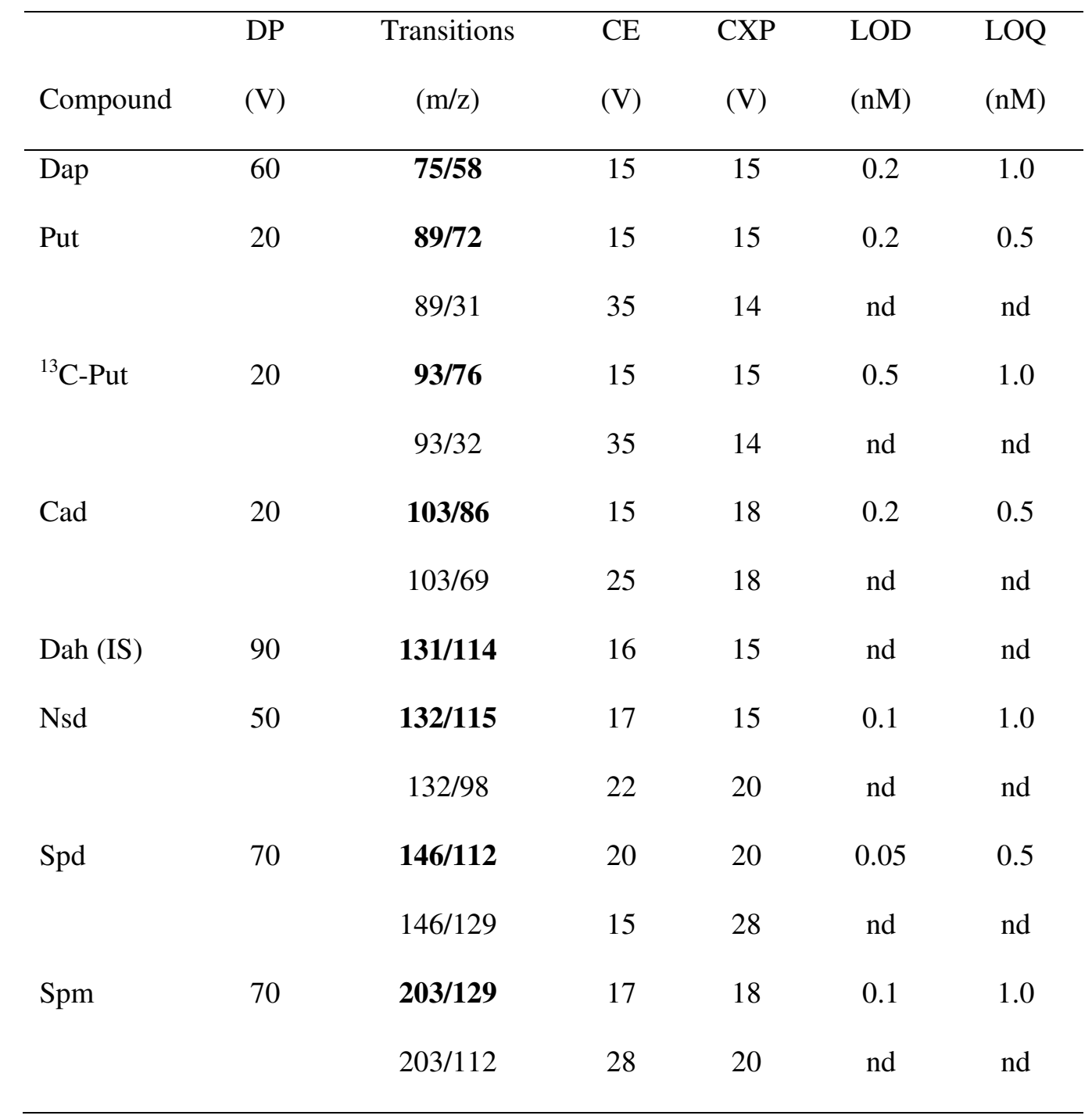


Polyamine variability and bacterial assimilation

Suppl. Table 3: DFPA concentrations in surface samples from different habitats on 18 February 2016 and the corresponding recovery (means of duplicates \pm range) measured with ${ }^{13} \mathrm{C}$-labeled putrescine added to samples at 1 and $10 \mathrm{nM}$ levels. Dap $=$ diaminopropane, Put $=$ putrescine, $\mathrm{Nsd}=$ norspermidine, $\mathrm{Spd}=$ spermidine, $\mathrm{Spm}=$ spermine, $\mathrm{nd}=$ not determined

\begin{tabular}{|c|c|c|c|c|c|c|}
\hline Habitat & $\begin{array}{l}\text { Dap } \\
(\mathrm{nM})\end{array}$ & $\begin{array}{c}\text { Put } \\
(\mathrm{nM})\end{array}$ & $\begin{array}{l}\text { Nsd } \\
(\mathrm{nM})\end{array}$ & $\begin{array}{l}\text { Spd } \\
(\mathrm{nM})\end{array}$ & $\begin{array}{l}\mathrm{Spm} \\
(\mathrm{nM})\end{array}$ & $\begin{array}{l}\text { Recovery (\%) } \\
1 \mathrm{nM} / 10 \mathrm{nM}\end{array}$ \\
\hline Lake Zurich & 2.5 & 18.8 & 0.3 & 1.3 & 0.3 & $101 \pm 4 / 97 \pm 3$ \\
\hline Türlersee & 2.3 & 9.5 & 0.1 & 0.5 & 0.2 & $90 \pm 12 / 98 \pm 1$ \\
\hline Hüttnersee & 1.5 & 10.4 & 0.2 & 0.7 & 0.1 & $124 \pm 5 / 123 \pm 3$ \\
\hline Thalwiler Waldweiher & 1.7 & 10.6 & 0.1 & 0.6 & 0.1 & $108 \pm 4 / 101 \pm 9$ \\
\hline Seleger Moor & 0.2 & 0.5 & nd & 1.4 & 0.1 & $121 \pm 20 / 109 \pm 5$ \\
\hline
\end{tabular}


Polyamine variability and bacterial assimilation

Suppl. Fig. 1: Ion chromatograms of (a) a mixture of 7 polyamines (20 $\mathrm{nM}$ each) in Milli-Q water, and (b) a biomass extract from the planktonic diatom Fragilaria sp. isolated from Lake Zurich. Dap: diaminopropane, Put: putrescine, ${ }^{13} \mathrm{C}$-Put: ${ }^{13} \mathrm{C}$-putrescine, Cad: cadaverine, Nsd: norspermidine, Spd: spermidine, Spm: spermine, Dah: diaminoheptane (internal standard).
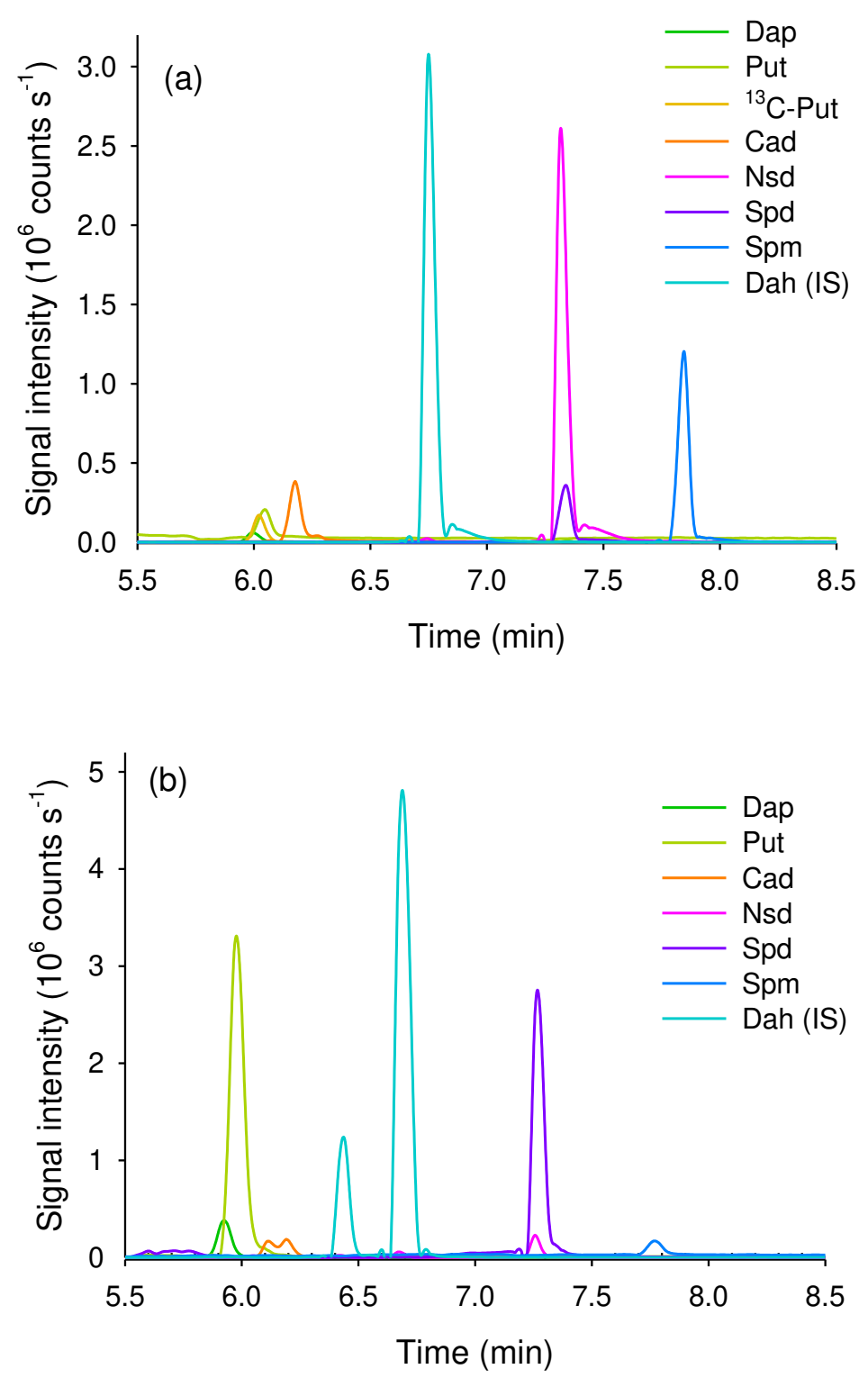
Polyamine variability and bacterial assimilation

Suppl. Fig. 2: Signal intensities of selected pairs of precursor and product ions (transitions) specific to norspermidine (Nsd), spermidine (Spd) and putrescine (Put) as a function of their concentration $(0.2-100 \mathrm{nM}$, note a logarithmic scale of the x-axis). Signal intensity of Nsd and Spd did not increase at concentrations $>50 \mathrm{nM}$ due to detector saturation indicated by a horizontal dashed line, whereas a continuous increase in signal intensity was observed for Put. Values are means of 3 replicates. Error bars show standard deviation.

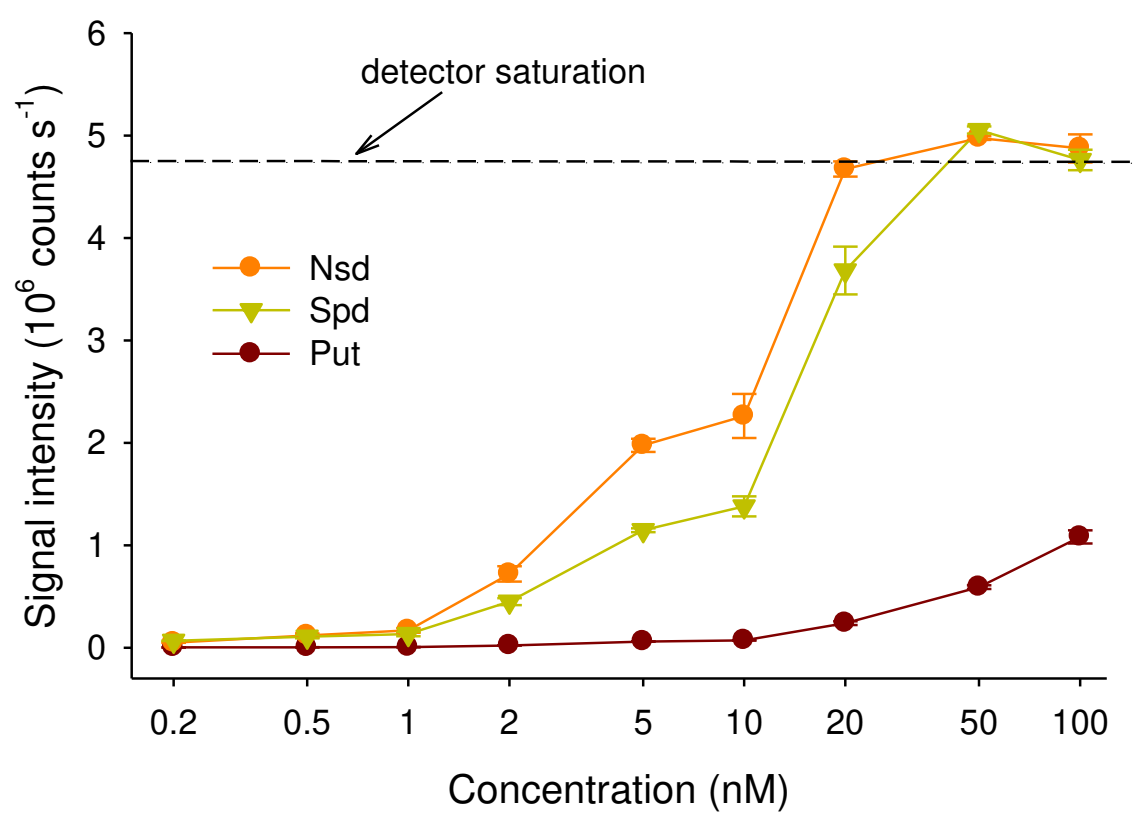


Polyamine variability and bacterial assimilation

Suppl. Fig. 3: Temporal changes in the concentrations of natural $\left({ }^{12} \mathrm{C}\right.$-Put) and isotopically labeled putrescine $\left({ }^{13} \mathrm{C}\right.$-Put $)$ in incubation experiment $\mathrm{V}$ conducted with filtered $(0.8 \mu \mathrm{m}$ membrane) epilimnetic samples (5 m) from Lake Zurich in July $2016 .{ }^{13} \mathrm{C}$-Put was amended at a concentration of $10 \mathrm{nM}$. Controls that were not amended with ${ }^{13} \mathrm{C}$-Put show concentrations of natural putrescine only. Values are means of 3 replicates. Error bars show standard deviation (range is shown for controls).

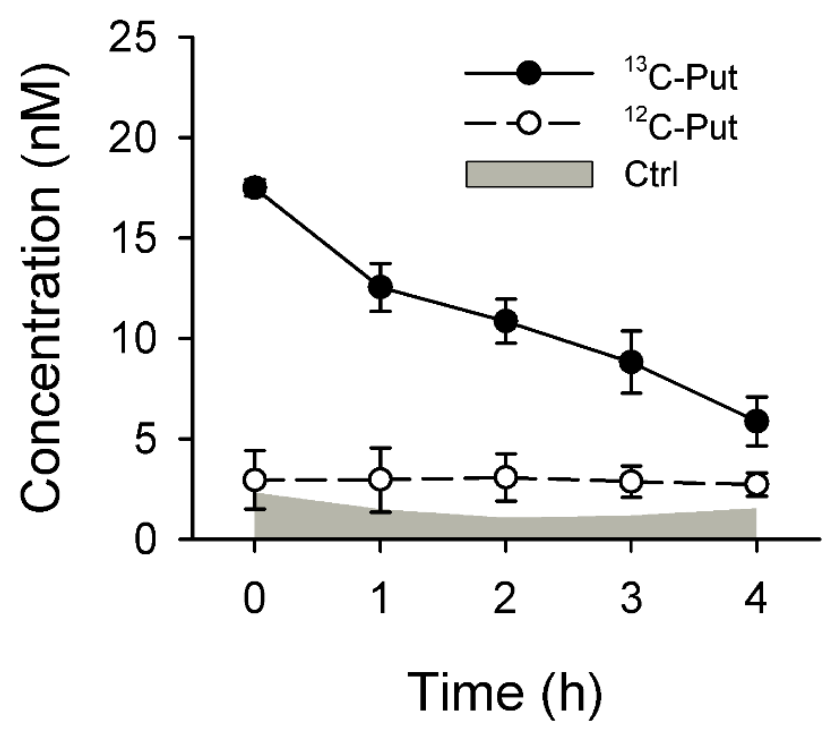

